\title{
The Wannsee Conference, the Fate of German Jews, and Hitler's Decision in Principle to Exterminate All European Jews*
}

\author{
Christian Gerlach \\ Technical University of Berlin
}

"The most remarkable thing about the meeting at Wannsee (which was not called the 'Wannsee Conference' until after the war) is that we do not know why it took place." So wrote the celebrated German historian Eberhard Jackel in $1992 .{ }^{1}$

Many historians share this view. They find themselves somewhat puzzled with respect to the meeting at Wannsee. ${ }^{2}$ On the one hand, the historical significance of the event is largely uncontested. The minutes prepared by Adolf Eichmann constitute a document of central importance. "No other document from the National Socialist regime," writes Wolfgang Scheffler, "sets out so clearly the complete plan for the extermination of European Jewry." " On the other hand, this uniqueness is itself problematic. Since we still know too little about the central planning for the extermination of the Jews, the relative significance of the Wannsee meeting is difficult to gauge. Nevertheless, some recent regional studies of the executions of Jews have shed new light on the protracted and complicated decision-making processes that went on within the

* Translated for the Journal of Modern History by Stephen Duffy, Simpson College. An earlier version was published as "Die Wannsee-Konferenz, das Schicksal der deutschen Juden und Hitlers politische Grundsatzentscheidung, alle Juden Europas zu ermorden,' WerkstattGeschichte 18 (October 1997). I am very grateful to Martina Voigt, Michael Wildt, Armin Nolzen, and Christoph Dieckmann for their advice and support during the preparation of this article. Independently of me, and at the same time, Peter Witte has come to similar conclusions about the dating of Hitler's decision to December 1941, a topic discussed in the third section.

${ }^{1}$ Eberhard Jackel, "Die Konferenz am Wannsee," Die Zeit (January 17, 1992), p. 33.

${ }^{2}$ Wolfgang Scheffler also noted that "the question has often been raised as to Heydrich's reasons for convening the conference at all." See Scheffler, "Die WannseeKonferenz und ihre historische Bedeutung," in Erinnern fur die Zukunft (Berlin, 1993), p. 17.

${ }^{3}$ Ibid. The authenticity of the document is not in question. See also n. 197 below. Eichmann himself identified it with no reservations. Of the works cited here, see esp. Scheffler; Johannes Tuchel, Am Grossen Wannsee 56-58: Von der Villa Minoux zum Haus der Wannsee-Konferenz (Berlin, 1992); Peter Klein, Die Wannsee-Konferenz vom 20. Januar 1942 (Berlin, n.d.), pp. 5-14.

[The Journal of Modern History 70 (December 1998): 759-812]

(C) 1998 by The University of Chicago. 0022-2801/98/7004-0001\$02.00

All rights reserved. 
German leadership. ${ }^{4}$ Other recent research has sought to interpret the course of events from the perspective of the central offices. ${ }^{5}$ Most significantly, however, documents connected with the Wannsee Conference itself have been uncovered, documents that provide us with important clues for interpreting previously known and published sources. What emerges is a new perspective on the course of events.

In the following essay I will attempt to show that, despite all the attention paid to it, the significance of the Wannsee Conference of January 20, 1942, has not been fully appreciated. First, it was a precondition not just for the execution of the "eastern Jews" but also for the extermination of German and western European Jews. Second, it was closely connected with Hitler's fundamental decision to proceed with the liquidation of all Jews living in Europe. In my opinion, Hitler made this decision in early December $1941 .{ }^{6}$ At least that is when he first made it public, with clear and calamitous consequences. It was not a solitary decision. Hitler was reacting to political impulses and initiatives that originated from within the administration and from inside the party apparatus. $^{7}$ In order to show this clearly, I will first examine the course of events through the end of 1941. By that time, a liquidation of the Jews had already begun in the German-occupied areas of the Soviet Union and in some other parts of eastern Europe. As of the autumn of 1941, however, when the mass

${ }^{4}$ For the General Government of Poland, see, e.g., Dieter Pohl, Von der "Judenpolitik" zum Judenmord: Der Distrikt Lublin des Generalgouvernements 1939-1944 (Frankfurt am Main, 1993), and Nationalsozialistische Judenverfolgung in Ostgalizien, 1941-1944 (Munich, 1996); Thomas Sandkuhler, Die "Endlosung” in Galizien (Bonn, 1996). For Serbia, see Christopher Browning, Fateful Months (New York and London, 1985), pp. 39-56, 68-85; Walter Manoschek, Serbien ist judenfrei (Munich, 1993). See also Yitzhak Arad, "The Holocaust of Soviet Jewry in the Occupied Territories of the USSR," Yad Vashem Studies 21 (1991): 1-47; Andrew Ezergailis, The Holocaust in Latvia, 1941-1944 (Washington and Riga, 1996). Additional studies of Lithuania by Christoph Dieckmann, of Einsatzgruppe D by Andrej Angrick, and of the Reich province Wartheland by Peter Klein and Michael Alberti are in preparation.

${ }^{5}$ For completely new approaches, see Gotz.Aly and Susanne Heim, Vordenker der Vernichtung (Hamburg, 1991); Gotz Aly, "Endlosung”: Volkerverschiebung und der Mord an den europaischen Juden (Frankfurt am Main, 1995). In addition, see Richard Breitman, The Architect of Genocide: Himmler and the Final Solution (London, 1992); Christopher Browning, The Path to Genocide (Cambridge, Mass., 1992); Hans Safrian, Die Eichmann-Manner (Vienna and Zurich, 1993); Philippe Burrin, Hitler und die Juden: Die Entscheidung fur den Volkermord (Frankfurt am Main, 1993).

${ }^{6}$ Up until now, the Dutch historian L. J. Hartog (in Der Befehl zum Judenmord: Hitler, Amerika und die Juden [Bodenheim, 1997], Dutch ed., 1994) is the only scholar to have provided documentary evidence in support of this view. I examine his position in detail below.

${ }^{7}$ This fundamental political decision has to be distinguished from Hitler's personal, inward decision to destroy the Jews of Europe. The latter would be extremely difficult to date (and this essay does not attempt to do so). 
deportations of Jews from the German Reich began, ${ }^{8}$ a decision to exterminate them had not yet been made. That becomes evident from the different kinds of treatment the German Jewish deportees received when they arrived at their various destinations. ${ }^{9}$

It was in this context that the Wannsee meeting was originally conceived. At this stage, its purpose - as I will show in the second section of this articlewas to resolve existing differences between governmental and party functionaries as to the future treatment of German Jews and, presumably, of Jews from the remainder of western Europe as well. In particular, one of its aims was to work out a viable definition of who was to be treated as a Jew. But the conference had to be postponed, and Hitler's fundamental decision to liquidate all European Jews, which I attempt to document in the third section, altered the context in which the meeting was eventually to take place. The extermination plans of the Reich Security Main Office (Reichssicherheitshauptamt, or RSHA), and of other offices, received a strong new impetus. The fourth section deals with the content and results of the Wannsee Conference. During the meeting, no objections were raised by the ministerial bureaucracy to a systematic liquidation of Jews from Germany or from the rest of Europe, though exceptions would continue to be made in the case of "part-Jews" (Mischlinge). Thus did systematic planning for the destruction of the Jews throughout Europe begin. In the fifth and final section I examine the consequences of the Wannsee Conference, above all for German Jews. It seems that the coordinated deportation of German Jews to the extermination camps began in early May 1942. But the RSHA's planned liquidation of part-Jews living in western and central Europe never took place, due to objections raised by the Reich interior and justice ministries, and to various other "difficulties."

\section{The Context: The Status of Extermination Efforts in EUROPE AT THE END OF 1941}

In order to evaluate the context of the Wannsee Conference, we need to review briefly the stage that the liquidation of Jews in Europe had reached at the close of 1941.

a) In the occupied territories of the Soviet Union, immediately following the German invasion of June 22, 1941, a systematic destruction of Jews began with the murder of men of military age. The executions were carried out by special mobile "task forces" (Einsatzgruppen) of the Security Police and the Security

\footnotetext{
${ }^{8}$ During 1940 and in the spring of 1941 several thousand Jews had already been deported from Stettin and Vienna to the Lublin district or from Baden to the south of France.

${ }^{9}$ Nationalsozialistische Vernichtungspolitik, 1939 bis 1945: Neue Forschungen und Kontroversen, ed. Ulrich Herbert (Frankfurt am Main, 1998).
} 
Service (SD), by police battalions, by brigades of the Armed SS (Waffen-SS), and, to a more limited extent, by rear guard units of the army. Beginning in August and September of 1941, women and children were also included. Beginning in September and October, entire Jewish communities were liquidated, initiating the phase of total destruction. ${ }^{10}$

b) In Serbia, brutal repressive measures implemented by the army were directed primarily at Jews. During the fall of 1941 a majority of Jewish men were murdered. ${ }^{11}$

c) In the General Government of Poland there were no systematic mass executions of Jews prior to the spring of 1942. The only exceptions occurred in the district of Galicia, which had, however, been a part of the Soviet Union up until June 1941. In Galicia, mass executions of Jews by the Germans began in October 1941. ${ }^{12}$ Construction of the extermination camp at Belzec in the district of Lublin was begun in November $1941 .{ }^{13}$ It was intended exclusively for the destruction of Jews. Its capacity was relatively limited, however, so that it could not have been designed for a rapid extermination of all Jews living in the General Government. ${ }^{14}$

d) In the annexed Reich province of the Wartheland, mass murders of Jews

${ }^{10}$ In occupied Lithuania the transition to total extermination had already occurred by the middle of August. Only in three larger cities did German authorities permit some thirty thousand Jewish workers and their families to survive. See Helmut Krausnick and Hans-Heinrich Wilhelm, Die Truppe des Weltanschauungskrieges: Die Einsatzgruppen der Sicherheitspolizei und des SD, 1938-1942 (Stuttgart, 1981); Arad, "The Holocaust of Soyiet Jewry," pp. 1-22; Ralf Ogorreck, Die Einsatzgruppen und die "Genesis der Endlosung” (Berlin, 1996); Christian Gerlach, "Wirtschaftsinteressen, Besatzungspolitik und Judenvernichtung in Weissrussland, 1941-1943," in Herbert, ed., pp. 263-91.

${ }^{11}$ Browning, Fateful Months, pp. 39 ff.; Manoschek, pp. 69 ff.

${ }^{12}$ In the former Polish areas that had been annexed by the Soviet Union in 1939, German units began a systematic execution of Jews in early October 1941 in order to reduce their numbers and thus be rid of "useless eaters." As a rule, however, they did not destroy entire Jewish communities until later. In those areas during 1941 approximately 15-25 percent of the Jewish inhabitants were killed. In the territories that had originally been part of the Soviet Union, and in the Baltic countries, virtually all Jews were executed. See Gerlach; Arad, "The Holocaust of Soviet Jewry," esp. pp. 18-22; Shmuel Spector, The Holocaust of Volhynian Jews, 1941-1944 (Jerusalem, 1990); for Galicia, see Pohl, Judenverfolgung, pp. $139 \mathrm{ff}$.

${ }^{13}$ Compare Adalbert Ruckerl, Nationalsozialistische Vernichtungslager im Spiegel deutscher Strafprozesse (Munich, 1977), pp. 106 f. and 132 f.; Yitzhak Arad, Belzec, Sobibor, Treblinka: The Operation Reinhard Death Camps (Bloomington, Ind., 1987), pp. 23-29; Ino Arndt and Wolfgang Scheffler, "Organisierter Massenmord an Juden in nationalsozialistischen Vernichtungslagern," Vierteljahrshefte fur Zeitgeschichte (hereafter cited as VfZ) 24 (1976): 105-35, esp. pp. 117-19. It is thought by some that the extermination camp at Sobibor was also under construction at this time. For a summary see Pohl, Von der “Judenpolitik,” p. 106.

${ }^{14}$ Pohl, in Von der “Judenpolitik,” p. 101, presents convincing arguments on this point. 
began in some areas in late September or early October 1941. At about this same time, construction was begun on an extermination camp in Chelmno, near Lodz. There, beginning on December 8, 1941, an SS-Commando unit used gas vans to exterminate Jews from neighboring districts. On January 16, 1942, the execution of Polish Jews from Lodz itself started. ${ }^{15}$

e) Sometime between September 14 and September 18, 1941, Hitler approved the inauguration of a program to deport German Jews to the eastern territories. For some time, Himmler, Heydrich, and various regional party leaders (Gauleiter) had been pressing him to do so. Starting on October 15, transports filled with Jews departed from cities throughout the Reich (including Austria and the Protectorate of Bohemia and Moravia). They were bound for Lodz, Minsk, Kaunas, and Riga. The German leadership, the SS, and the police viewed these transports as an interim measure. Organizational and technical problems limited the deportations to a small fraction of the Jews living in Germany. It was also in September of 1941 that the deportation of French Jews, limited initially to those being held in detention, was announced. ${ }^{16}$

The point of transition to a policy of exterminating the Jewish people, or the initial preparations for it, can thus be clearly seen in a number of occupied territories and regions beginning in September and October of 1941. Total liquidation began in the occupied Soviet lands. Selective mass executions of those seen as "unfit for labor" began in western Ukraine, in western White Russia, and in the Wartheland. In Serbia, executions of Jewish men served as a prelude to the murders of women and children, groups that were "useless" in the eyes of the occupation authorities. In the context of these developments, most historians have hitherto equated the decision to deport German Jews with the decision to liquidate them. At the most, it is assumed that there were two separate decisions. One, involving the execution of Soviet Jews, would have occurred in July or August of $1941 .{ }^{17}$ The second, concerning the extermination of Jews

${ }^{15}$ Arndt and Scheffler, pp. 116 ff.; Ruckerl, pp. 259-68; Aly, p. 355; Florian Freund, Bertrand Perz, and Karl Stuhlpfarrer, "Das Getto in Litzmannstadt (Lodz)," in "Unser einziger Weg ist Arbeit.” Das Getto Lodz, 1940-1944 (Frankfurt am Main, 1990), pp. $17-31$.

16 The best summary, along with new evidence, can be found in Peter Witte, "Two Decisions concerning the 'Final Solution to the Jewish Question': Deportations to Lodz and Mass Murder in Chelmno," Holocaust and Genocide Studies 9, no. 3 (1995): 318-45.

${ }^{17}$ Browning, The Path to Genocide (n. 5 above), (July); Ogorreck; and Burrin (n. 5 above), (August). Earlier works date the decision to execute Soviet Jews to the spring of 1941. See Gerald Reitlinger, Die Endlosung: Hitlers Versuch der Ausrottung der Juden Europas, 5th ed:.(West Berlin, 1979), pp. 89 ff.; Helmut Krausnick, "Die Einsatzgruppen vom Anschluß Osterreichs bis zum Feldzug gegen die Sowjetunion,” in Krausnick and Wilhelm, pp. 107 ff. and 150 ff.; Raul Hilberg, Die Vernichtung der europaischen Juden, rev. and expanded ed. (Frankfurt am Main, 1990), pp. 288 ff. (sometime before June 22, 1941). 
from the rest of Europe, is supposed to have been reached in September or October of that year. ${ }^{18}$ There are some historians, it must also be noted, who would date these decisions as early as January 1941, or even earlier. ${ }^{19}$

The Wannsee Conference was a meeting between representatives from the RSHA and state secretaries and other officials from the ministerial bureaucracy. Its purpose was to discuss the "Final Solution of the Jewish Question." It took place on January 20,1942. It had originally been scheduled to occur on December 9, 1941. Initial invitations to participate had gone out on November 29 .

These dates are clearly later than the turning point that apparently occurred in the extermination policy in the early fall of 1941. Hence, according to the prevailing view, the purpose of the meeting could not have been a decision about whether to proceed with exterminations. Rather, its purpose must have involved secondary issues such as the division of authority, coordination, and organization. According to the minutes, ${ }^{20}$ a variety of topics were discussed, and scholars differ as to which were the most important. Heydrich described the European-wide extermination program to the ministerial representatives in attendance. ${ }^{21} \mathrm{He}$ furnished them with information and tried to persuade them to accept his ultimate authority in the matter. ${ }^{22}$ Heydrich also wanted to clear up any problems or differences of opinion arising from the inclusion of western, northern, and southeast European Jews, German "part-Jews," and Jews working in the armaments industry. His aim was a unified, coordinated effort. ${ }^{23}$

Certainly none of these topics was insignificant. But there was one particular

${ }^{18}$ Burrin, pp. 133 ff. (September); Browning, The Path to Genocide (October); Uwe Dietrich Adam, Judenpolitik im Dritten Reich (Dusseldorf, 1979), p. 312 (between September and November); Raul Hilberg, "Die Aktion Reinhard," in Der Mord an den Juden im Zweiten Weltkrieg, ed. Eberhard Jackel and Jurgen Rohwer (Frankfurt am Main, 1987), pp. 125-36, esp. p. 126 (during the summer).

${ }^{19}$ As in Breitman (n. 5 above), pp. $145 \mathrm{ff}$; f for a more cautious view, see Leni Yahil, The Holocaust: The Fate of European Jewry, 1932-1945 (New York and Oxford, 1990), esp. pp. 253 and 320.

${ }^{20}$ A facsimile of the original has been published in John Mendelsohn, ed., The Holocaust: Selected Documents in Eighteen Volumes, vol. 11 (New York and London, 1982); and in Tuchel, pp. 121-36 (along with Heydrich's letter of February 26, 1942, to the Foreign Office). Hereafter I cite Tuchel.

${ }^{21}$ Reitlinger, pp. $105 \mathrm{ff}$.

${ }^{22}$.Scheffler (n. 2 above), pp. 24 f. and p. 30 . The second point is emphasized especially by Jackel (n. 1 above).

${ }^{23}$ Hilberg, Vernichtung, p. 421. The first two aspects are emphasized by Adam, p. 314, because they were the only issues that had not been resolved beforehand. For a combination of the various elements as more or less equally important, see Aly and Heim, p. 455; Kurt Patzold and Erika Schwarz, Tagesordnung: Judenmord. Die Wannsee-Konferenz am 20. Januar 1942, 2d ed. (Berlin, 1992), pp. 33 ff.; Klein; Wolf Kaiser, "Die WannseeKonferenz," in Tater-Opfer-Folgen: Der Holocaust in Geschichte und Gegenwart, ed. Heiner Lichtenstein and Otto R. Romberg (Bonn, 1995), pp. 24-37, esp. pp. 28 ff. 
issue that made the meeting seem of utmost urgency in the eyes of the men who were responsible for shaping the extermination policy. This comes as something of a surprise, given the prevailing view that the decision had been made much earlier. Postwar testimony by some of the participants gives us an indication of the importance they attached to the resolution of this issue at the time of the conference. Georg Heuser, then head of the Gestapo offices in Minsk, testified that in the period before the Wannsee Conference "only eastern Jews" were to be executed. "Initially, German Jews were supposed to be resettled in the east. After the Wannsee Conference, we were told that all Jews were to be liquidated." ${ }^{24}$ Furthermore, in his initial testimony, Adolf Eichmann also declared that "the Wannsee Conference was indeed the beginning of the real extermination story." ${ }^{25}$ Eichmann's interrogator, and after him many historians, countered that the murder of Jews in the Soviet Union had already begun; ${ }^{26}$ but of course Eichmann's statement could have referred only to the executions that he himself had to organize.

These statements by Heuser and Eichmann reveal that the authorities evidently still had to face another "problem" at the close of 1941, despite the prevailing notion that a decision on this matter had already been made earlier: should-or, more precisely, could_German Jews be executed, too?

\section{The Original Theme of the Wannsee Conference: The Definition and Treatment of German Jews}

On the afternoon of November 30, 1941, Himmler held a telephone conversation with Heydrich. After the call, he jotted down the notation: "Jewish transport from Berlin. no liquidation." ${ }^{27}$ The call itself came too late. The Berlin Jews, some one thousand of them, whose transport had left Berlin on November 27, had already been shot to death near Riga on the morning of November $30 .{ }^{28}$ The radical right-wing British historian David Irving, relying on this nota-

\footnotetext{
${ }^{24}$ Interrogation of Georg Heuser, March 18, 1969, Staatsanwaltschaft (StA) Mainz 3 Ks 1/67, Protokolle B, vol. 1 (Hauptverhandlung), fol. 177. It should be emphasized that this statement was made during legal proceedings. There had been no prior preparations in which this formulation could have been suggested to Heuser. Furthermore, this particular issue had nothing to do with the subject of the proceedings, which concerned Jewish executions in Lida.

${ }^{25}$ Interrogation of Adolf Eichmann, June 6, 1960, cited in State of Israel, Ministry of Justice, The Trial of Adolf Eichmann: Records of the Proceedings in the District Court of Jerusalem, vol. 7 (Jerusalem, 1995) (cited hereafter as Trial of Adolf Eichmann) (Ton-)Band 5, fol. 5 (p. 169).

${ }^{26}$ Ibid.; and Jackel, p. 34.

${ }^{27}$ Himmler, notes on telephone conversations, November 30, 1941, Bundesarchiv (BA) NS 19/1438.

${ }^{28}$ Gerald Fleming, Hitler und die Endlosung: "Es ist des Fuhrers Wunsch. . .” (Wiesbaden and Munich, 1982), pp. $88 \mathrm{ff}$.
} 
tion made by Himmler, once claimed that Hitler had decided to put a stop to the extermination of the Jews in general. Serious historians have refuted this absurd notion. But the jotted notation has led some historians to surmise that executions of German Jews had aroused quite a stir among German authorities and had caused Himmler to suspend, for a time, any further executions of Jews from Germany. ${ }^{29}$ In fact, the executions were carried out on local initiatives, and against Himmler's wishes, as shown by sources recently uncovered by the German historian Christoph Dieckmann. On the following day, December 1, Himmler sent a radio transmission to Friedrich Jeckeln, the Higher SS and Police Leader (Hoherer SS- und Polizeifuhrer, or HSSPF) for the Ostland and the person responsible for the Riga executions, stating that "unauthorized actions, or actions contrary to directives issued either by me or by the Reich Security Main Office under my authority" with respect to the "treatment of Jews resettled in the Ostland" would be "punished." Later in the same day, Himmler directed Jeckeln to meet with him on December $4 .^{30}$ Whether or not Hitler was involved at this point is not known. What is known is that the dinner conversations that took place in Hitler's presence on the first or second of December dealt with the subjects of Jewish mixed marriages, part-Jews, and, possibly, Jewish frontline fighters as well. Hitler's own remarks on the occasion are ambiguous. ${ }^{31}$

Let us take a closer look at the fate of the deportation trains from Germany for the year 1941. First, some twenty thousand German Jews were transported to Lodz between October 15 and November 4. Many died from starvation, but there were no executions. Protests from the regional administration, under its president, Uebelhor, had succeeded in reducing the number of proposed deportees from sixty thousand to twenty-five thousand. ${ }^{32}$ There is no evidence from Lodz to indicate that any consideration was being given to the idea of executing the Jews who arrived from Germany. In the middle of January 1942, when the civil administration and the SS police apparatus began to transport Jews from

${ }^{29}$ See Martin Broszat, "Hitler und die Genesis der 'Endlosung': Aus Anlass der Thesen von David Irving," VfZ25 (1977): 739-75, esp. pp. 760 ff.; Scheffler, p. 20; Aly and Heim (n. 5 above), p. 465; David Irving, Hitler's War (London, 1977), pp. 330-32. It remains uncertain who called whom and whether the suggestion not to execute the deported German Jews originated with Himmler or with Heydrich.

${ }^{30}$ Two radio messages from Himmler to Jeckeln, December 1, 1941, Public Record Office, HW 16/32, GPD 471 Nr. 2 (for December 4, 1941). I am very grateful to Christoph Dieckmann for this reference. See also Himmler, appointment calendar, December 4, 1941, OSOBYi archives Moscow 1372-5-23, fol. 350. Himmler noted three topics for the meeting: "Jewish question | SS Brigade. Business enterprisess."

${ }^{31}$ Werner Jochmann, ed., Adolf Hitler: Monologe im Fuhrerhauptquartier: Die Aufzeichnungen Heinrich Heims (Munich, 1982), pp. 147-49 (dated December 1-2, 1941).

${ }^{32}$ See Hilberg, Vernichtung (n. 17 above), pp. 222-24. Among them were 5,000 gypsies from the Burgenland. 
the Lodz ghetto to the extermination camp at Chelmno, the Jews from Germany were initially excluded..$^{33}$

A second destination for the transports was Minsk. Between November 8 and November 28, 1941, some seven thousand Jews from the old Reich, from Vienna and Brunn, were deported there. ${ }^{34}$ All the German Jews were herded into the ghetto. Initially, there were no executions. To make room for these arriving German Jews, 6,624 White Russian Jews had been shot to death by the Security Police and the SD between November 7 and November 11. On November 20, another five thousand were executed. The deportation plan had in fact called for some twenty-five thousand Jews to be transported to Minsk, but the transports were canceled due to protests from the Army Group Center (Heeresgruppe Mitte), whose rail and supply situation had become critical during the Battle of Moscow. ${ }^{35}$

The situation was different in Kaunas, in Lithuania, the third destination point. Between November 25 and November 29 a total of 4,934 Jews arrived there from Germany and Austria. Einsatzkommando 3 of the Security Police and the SD shot them all. ${ }^{36}$ In the absence of documentary source material, it is not clear where the orders for these murders originated. It has sometimes been argued that these transports were diverted to Kaunas unexpectedly and with little advance notice, and that the Jewish deportees were simply executed "to get rid of a problem," as it were. But plans to send the first five trains to Kaunas in the Baltic had been announced three weeks earlier. ${ }^{37}$ Just three days

${ }^{33}$ See n. 209.

${ }^{34}$ Urteil LG Koblenz 9 Ks 2/62, May 21, 1963, in Adelheid L. Ruter-Ehlermann et al., eds., Justiz und NS-Verbrechen, vol. 19 (Amsterdam, 1979), p. 190; undated report of Einsatzgruppe A and of the Commander of the Security Police and the SD in Minsk (January 1942), Institut fur Zeitgeschichte (IfZ) Fb 101/34 and Fb 104/2.

${ }^{35}$ On November 11 the first transport from Hamburg arrived in Minsk. On November 14, the chief of the general staff of the Army Group Center, Major General Hans von Greiffenberg, issued a communication by telephone to General Walter Braemer, the commander of the armed forces in the Ostland, in Riga, to lodge a protest with the Head of Transportation in the Army's High Command. Braemer did so by November 20 at the latest. His protest led to an immediate cancellation of other scheduled transports, with the exception of one train that left Cologne on November 28. See war diary of Army Group Center, November 11 and November 14, 1941, Bundesarchiv-Militararchiv (BA-MA) RH 19 II/387, fols. 55, 63; Safrian (n. 5 above), p. 150; Chef Sipo/SD, Incident Report Nr. 140, December 1, 1941, BA-MA SF-01/28934.

${ }^{36}$ Einsatzkommando 3, Report, December 1, 1941, Zentrale Stelle der Landesjustizverwaltungen Ludwigsburg (ZStL), UdSSR, vol. 401, fol. 91, published in facsimile in Heinz Artzt, Morder in Uniform (Munich, 1979), esp. p. 189.

${ }^{37}$ Einsatzgruppe A to the Reich Commissar for the Ostland, November 8, 1941, BA R 90/146. According to a handwritten notation, shortly thereafter the Reich Commissariat for the Ostland (RKO) sent a copy to the General Commissar for Lithuania in Kaunas, who was thus notified in advance as well. 
before the first massacre, Dr. Peter Kleist, the section chief for the Ostland in the Reich Miniștry for the Occupied Territories in the East (Ostministerium), met with Karl Jager, the head of Einsatzkommando 3 in Kaunas, and expressed his satisfaction with the executions of Lithuanian Jews. We are thus justified in concluding that the Ministry for the East, which had been informed about the transports, was in agreement with the plan to execute the German Jews who were expected to arrive in Kaunas. ${ }^{38}$ Only the discovery of new documents will be able to shed light on the question of how and by whom this decision was reached, and whether or not any misgivings were voiced by German officials.

It was at the fourth destination point, Riga, that on November 30, 1941, one day after a second mass execution of Jews had occurred in Kaunas, all the deportees on a train from Berlin were murdered. As mentioned above, the executions were carried out by Jeckeln, the Higher SS and Police Leader in the Ostland, using his own units. Later on the same day Jeckeln called in Einsatzkommando 2 to assist at the executions of several thousand Latvian Jews. ${ }^{39}$ Hinrich Lohse, the Reich Commissar for the Ostland (Reichskommissar fur das Ostland), was also present at this massacre..$^{40}$ Only two days earlier Lohse had dropped his opposition to the deportation of German Jews into "his" Reich Commissariat, acceding to the wishes of the Ministry for the East. ${ }^{41}$ Nevertheless, the execution of the Jews transported from Berlin aroused quite a stir. ${ }^{42}$

${ }^{38}$ Kleist, personal notebook, entry for November 22, 1941, Staatsanwaltschaft Hamburg 147 Js 29/67, vol. 65, fol. 12460. Before handing over his notes to the authorities, Kleist had made one of these lines illegible (as he did in several other sensitive passages). But he overlooked the following passage: "Very good impression by Staf. Jager. He agrees completely with Lith.[uanian] cooperation. If the local administration can be involved in this sensitive area, then there will be no excuse for other areas." It is known that Jager made widespread use of Lithuanian commandos in the executions of Jews. On November 21, Kleist made the following notation on his stay in Kaunas: "Afternoon in the ghetto, chicken in the pot, isolation hospital, covered graves next to it."

${ }^{39}$ Safrian (n. 5 above), p. 153. See also the interrogation of Friedrich Jeckeln, December 14, 1945, Bundesarchiv-Zwischenarchiv Dahlwitz-Hoppegarten (BA D-H) ZM 1683 , vol. 1 , fols. $12 \mathrm{f}$.

${ }^{40}$ This was reported the next day to Kleist by officials of the Reich Commissariat Ostland in Riga: "Told about shootings of 10,000's of German and Latvian Jews by SS. Reich Commissar was witness." Kleist, personal notebook, entry for December 1, 1941, StA Hamburg 147 Js 29/67, vol. 65, fol. 12460. Kleist received the news of the massacre of the German Jews with no visible reaction. This, too, suggests agreement by the Ministry for the East. After the war, Lohse voluntarily admitted that he had witnessed a mass execution in Riga in Jeckeln's presence. He put its date at the beginning of December 1941. See interrogation of Hinrich Lohse, April 19, 1950, Staatsanwaltschaft Hannover 2 Js 499/61, Sonderheft 4, fols. $82 \mathrm{ff}$.

${ }^{41}$ Safrian, p. 149.

${ }^{42}$ Frank Flechtmann, “November 1944: 'Und nun erst recht!' Ein Hornberger lasst schiessen" (Die Ortenau [1996]: 471-91, esp. p. 482). It is asserted, with no source cited, that reports of the event had been broadcast that same evening by British and Soviet radio. 
After this incident, German Jews arriving in Riga were no longer executed immediately. Instead they were held in confinement in temporary camps outside the city. Because living conditions there were atrocious, many died within a short time. Others were shot by the guards, or murdered in the Bikerniki forest. A transport that arrived from Cologne on December 10 was the first whose occupants were permitted to take up residence in the Riga ghetto. Another fourteen transports followed. ${ }^{43}$ During December 1941 and January 1942 several thousand Jews apparently died. The toll was especially heavy in the camps. According to some accounts, purportedly by eyewitnesses but difficult to verify, all deportees on several trains that arrived later in December 1941 were executed. Einsatzkommando 2 is reported to have separated out the weak and infirm and executed them. Attempts were made to conceal the murders, so that the reason for the selections would not become known "to local Jews or to Jews in the Reich." 44

Let us quickly summarize these rather gruesome results. A general order to execute German Jews had not yet been issued. In Lodz and Minsk, German officials and police allowed German Jews arriving in 1941 to survive. In Kaunas, however, all the arriving Jews were murdered. In Riga, finally, Jews on the first transport were openly killed. Those arriving later were initially kept alive, only to be shot later in "smaller" executions or to be killed by the horrendous living conditions, particularly the cold. Direct executions were concealed as much as possible.

Objections were raised almost immediately by the civilian administrations. They did not oppose the executions per se, but rather the deportations of nonJews or privileged Jews, which could lead to the killing of people who had not been targeted and thus jeopardize political support for the "Final Solution" in general. Both Wilhelm Kube, general commissar in Minsk, and Hinrich Lohse sent to the Ministry for the East lists with the names of individuals who should not have been transported to the east, at least according to the rules then governing the deportations. The lists had been given to them by German Jews in

The assertion is based on eyewitness accounts from some of the perpetrators at their trial after the war. I am grateful to Dieter Pohl for calling my attention to this publication. On December 19, a report of the incident reached the Reich interior ministry; see Bernhard Losener, "Als Rassereferent im Reichsministerium des Innern," VfZ 9 (1961): 264-313, esp. p. 310 .

${ }^{43}$ See Ezergailis (n. 4 above), pp. 352-59; Hans-Heinrich Wilhelm, Die Einsatzgruppe A der Sicherheitspolizei und des SD, 1941/42 (Frankfurt am Main, 1996), pp. 124-31; excerpt from an undated report of Einsatzgruppe A, in Patzold and Schwarz, eds. (n. 23 above), pp. $99 \mathrm{f}$.

${ }^{44}$ Undated report of Einsatzkommando 2, cited in Wilhelm, p. 130. See also Bernhard Press, Judenmord in Lettland, 1941-1945 (Berlin, 1992), pp. 117-19; Reitlinger (n. 17 above), p. 103. 
the Minsk and Riga ghettos. On November 29, Kube had visited the separate "German ghetto" in Minsk. He subsequently issued a complaint that among the deportees there were many so-called "part-Jews" (who were not considered Jews under the Nuremberg laws), Jews married to "Aryans," brothers of army servicemen, and decorated veterans of World War I. He lodged an immediate protest at the Ministry for the East. It appears to have been received there by December 8, at the latest. ${ }^{45}$ Lohse's reaction a short time later was similar, though less dramatic. Both objections, along with the lists of names, were forwarded to Heydrich by the deputy minister for the East, Alfred Meyer. ${ }^{46}$

This chronological sequence makes it clear, admittedly, that the objections raised by these two officials could not have been a decisive factor in the halting of the executions. ${ }^{47}$ But these certainly could not have been the only protests. As early as October 10, Heydrich had declared that "no special consideration should be shown to Jews decorated during the war. On the contrary," they should be "transported in percentages corresponding to their actual numbers." ${ }^{48}$ On November 20, Eichmann had circulated a memo outlining deportation directives. Its effect was to reduce the number of victims affected. Apparently Eichmann's actions came because the RSHA had already received some

${ }^{45}$ See Kleist, personal notebook, entry for December 8, 1941: "Jew-Kube-shot? Schmitz," StA Hamburg 147 Js 29/67, vol. 65, p. 12460. Schmitz was the relevant official in Section I (Politics) of the Ministry for the East. See also official report of the commander of the Security Service in Minsk, November 29, 1941; and Heydrich's reply to Kube, March 21, 1942, in report of Strauch, Abwehroffizier of the Head of the Antipartisan Units of the Reichsfuhrer-SS, to his Supervisor, Bach-Zelewski, July 25, 1943, BA NS 19/1770, fols. 15-27 (published in Helmut Heiber, "Aus den Akten des Gauleiters Kube," VfZ 4 [1956]: 67-92, esp. pp. 83-85 and p. 90 [notation dated December 2, 1941]); report of Burkhart, adviser on Jewish Affairs for the Commander of the Security Service in Minsk, January 1942, IfZ Fb 104/2. Kube took notice of the matter relatively late because he had been in the Reich between November 10 and November 20 . See Kleist, personal notebook, entry of November 17, 1941; interrogation of H. v. R., May 18, 1966, Staatsanwaltschaft Hamburg 147 Js 29/67, fols. 7149 f., and the indictment for the same case, Anklageschrift, ibid., pp. $446 \mathrm{ff}$.; Kube to Rosenberg, November 4; Marquardt to DAF-Oberfuhrer Zillig, November 18, 1941, BA R 6/27, fols. 23,26 .

${ }^{46}$ As mentioned by Eichmann on March 6 at a conference to discuss the new deportation directives, according to notes made by a police inspector from the State Police Office in Dusseldorf, March 9, 1942. See H. G. Adler, Der verwaltete Mensch: Studien zur Deportation der Juden aus Deutschland (Tubingen, 1974), pp. 194 ff.

${ }^{47}$ One must concur with Safrian (p. 167, n. 96), who finds it unlikely that Kube's protest following his visit to the ghetto on November 29 would have reached Himmler just twenty-four hours later.

${ }^{48}$ Note dated November 10, 1941, in re the "Solution of Jewish Questions," Eichmann Trial Document Nr. 1193, BA F 5493. In Heydrich's opinion, only "a few special Jews under the protection of higher Reich offices" should be spared, "in order to avoid too great a volume of requests for the sake of such Jews." 
complaints and was expecting more to follow. ${ }^{49}$ Heydrich's comments to Goebbels also suggest that this was the case. Heydrich planned to use the new camp at Theresienstadt in the Protectorate of Bohemia and Moravia to intern Jews who were more than sixty years old or who might be regarded as "doubtful cases." ${ }^{50}$ But complaints were received anyway, because Eichmann's directives were not followed. In early November, in Berlin, two prominent individuals intervened on behalf of Dr. Karl Lowenstein, a Jewish attorney who was deported to Minsk in spite of the guidelines. ${ }^{51}$ On February 6, 1942, Heinrich Muller, the chief of the Gestapo, wrote that "anonymous letters are constantly arriving, from practically all areas of the Reich" concerning incidents involving mass executions of Jews. ${ }^{52}$ As I noted earlier, the numerous protests against including the so-called "part-Jews," decorated war veterans, and Jews married to "Aryans" had obviously contributed to Himmler's November 30, 1941, order halting the executions temporarily.

Before further measures could be taken against the deported German Jews - and there were officials who were pressing for quick executions ${ }^{53}$ there had to be a clear and unambiguous definition of who should be included. ${ }^{54}$ In order to formulate this definition, there would have to be a meeting of the government officials involved in the operation. That meeting was the

${ }^{49}$ It seems that the RSHA did make exceptions for, among others, decorated war veterans. In a teletype dated April 17, 1942, Eichmann referred to the directive of November 20,1941 , and stated that Jews with decorations for wounds received during the war "are also exempt from deportation to the east" (quoted in Fleming [n. 28 above], p. 129, n. 258 [emphasis added]). In fact the deportation directives had been issued prior to November 20, 1941. See Adam (n. 18 above), p. 316.

${ }^{50}$ See entry in Goebbels of November 18, 1941, quoted in Broszat (n. 29 above), p. 752.

${ }^{51}$ The individuals were (Hellmuth James) Graf v. Moltke and Lieutenant-Commander Albrecht. See undated memoir by Karl Loewenstein, before June 1, 1956, copy in the Bibliothek des Zentrums fur Antisemitismusforschung, Berlin. For violations of the deportation guidelines in the case of the Riga transports see also Fleming, pp. 88 f., n. 188.

${ }^{52}$ Quoted in Andreas Seeger, "Gestapo Muller": Die Karriere eines Schreibtischtaters (Berlin, 1996), p. 121.

${ }^{53} \mathrm{Dr}$. Wetzel, the racial adviser in the Ministry for the East, wrote to Lohse on October 25, 1941 (draft, Nuremberg Document NO-365). What he wrote can be interpreted to mean that Lohse, too, wanted to eliminate German Jews incapable of work using "Brack's method," i.e., poison gas, and that the Ministry for the East expressed "no reservations." But the meaning is not absolutely clear. I am grateful to Christoph Dieckmann for calling my attention to this reference. The authenticity of the document was confirmed by Erhard Wetzel during his interrogation, September 20, 1961, Staatsanwaltschaft Hannover 2 Js 499/61, vol. 2, fols. $18 \mathrm{ff}$.

${ }^{54}$ Aly and Heim (n. 5 above), pp. 468 ff., have emphasized this issue. See also John A. S. Grenville, "Die 'Endlosung' und die 'Judenmischlinge' im Dritten Reich," in Das Unrechtsregime, vol. 2: Verfolgung, Exil, Belasteter Neubeginn, ed. Ursula Buttner (Hamburg, 1986), pp. 91-121, esp. p. 108; see also Adam, pp. 314 ff.; with regard to the deportations, see Hilberg, Vernichtung (n. 17 above), p. 421. 
Wannsee Conference. In retrospect, the acting Reich Justice Minister Franz Schlegelberger summed up the situation as follows: "The final solution of the Jewish question presupposed a definitive and final determination of the class of individuals who were to be affected by the proposed measures." ${ }^{55}$ This was to be the principal topic of discussion at the conference. Most of the meeting's participants had to deal with the issue directly: Heydrich, Muller, and Eichmann (from the RSHA); Otto Hofmann (SS-Race and Resettlement Office); Wilhelm Kritzinger (Reich chancellery); Wilhelm Stuckart (Reich interior ministry); Gerhard Klopfer (Party chancellery), and Roland Freisler (Reich justice ministry). Others faced it indirectly: Erich Neumann (Four-Year Plan Office), Alfred Meyer, and Georg Leibbrandt (Ministry for the Occupied Territories in the East). ${ }^{56}$ The German Jews were to be the primary focus. Many of those invited to attend had no official interest whatever in the fate of Jews from the occupied territories. The representatives from the Reich chancellery, from the Party chancellery, from the interior ministry, and from the justice ministry were concerned solely with Jews in Germany, as can be seen, for example, from a document prepared for Stuckart's use at the Wannsee Conference by the adviser on Jewish affairs in the Reich interior ministry, Bernhard Losener. ${ }^{57}$ In the initial invitations, Heydrich had indicated, with good reason, how important the discussion would be for all officials involved in the "Final Solution," "particularly because Jews from the Reich territory, including the Protectorate of Bohemia and Moravia, have been evacuated to the east in ongoing transports since October 15, 1941." ${ }^{58}$ What he obviously had in mind was the ques-

${ }^{55}$ Franz Schlegelberger to Hans-Heinrich Lammers, April 5, 1942, in "Re: The Final Solution of the Jewish Question," published in Mendelsohn, ed. (n. 20 above), vol. 18, p. 201.

${ }^{56}$ The Ministry for the East was involved in the issue of the definition of German Jews because the individuals deported to Riga and Minsk had been stripped of their citizenship according to the eleventh ordinance to the Reich Citizenship Law of November 25, 1941, and were thus subject to the guidelines in effect there. For the same reason, the problem of the definition of Jews in the occupied Soviet territories, which had not yet been resolved, was connected with this question. Cf. BA R 6/74. See Ordinance 11 with addendum, December 3, 1941, and its history in BA R 43 II/136a. For the Four-Year Plan Office, see Document 1 with Bernhard Losener's (Reich interior ministry) notation, December 4, 1941, BA R 18/5519, fols. 483-85. The other participants at the meeting were Undersecretary of State Martin Luther (Reich foreign ministry) and two "practitioners" of mass execution from the occupied territories, Schongarth and Lange, the heads of the Security Police and the SD in the Government General and in Latvia. See the biographies in Patzold and Schwarz, eds. (n. 22 above), pp. 201-45.

${ }^{57}$ See Bernhard Losener's notation, December 4, 1941, with two attached documents, BA R 18/5519, fols. 477, and 483-95.

${ }^{58}$ Heydrich to Undersecretary of State Luther, November 29, 1941, reproduced in facsimile in Tuchel (n. 3 above), pp. 112 ff.; emphasis added. 
tion of what should be done with them. As it turned out, according to the minutes, the problem of specifying who the Jewish victims were to be occupied a considerable amount of time and led to the only open differences of opinion..$^{59}$

Heydrich had sent out the initial invitations on November 29. That date was shortly before the executions were temporarily halted. Clearly, problems and complaints arising in connection with the deportations had surfaced even before the events in Riga. But after the Riga murders they became more pressing. The issues involved were brought out with extreme clarity in a letter addressed by the Minsk general commissar, Wilhelm Kube, to his superior, Lohse, in Riga on December 16, 1941. In his letter, Kube explained that German Jews, "who come from our own cultural milieu," are "just not the same as the animal hordes from these regions." At the same time, however, Kube wrote to request "an official directive" to execute them. He wanted to avoid issuing such an order "on [his] own authority." 60

With regard to the issues on the agenda for the Wannsee Conference other than the treatment and definition of the German Jews, the RSHA had already reached complete or nearly complete agreement with the other offices involved even before the conference took place. ${ }^{61}$ On October 23, 1941, just prior to the initial deportations, the RSHA and the Economics and Armaments Office of the Armed Forces High Command had reached an accord concerning Jews working in the armaments industry inside the Reich. According to Eichmann's testimony, none of these Jews would be deported without specific approval from those in charge of the relevant armaments. Heydrich had included this

${ }^{59}$ Undated minutes, fols. 8 f., 10-14 (Tuchel, pp. 129-35).

${ }^{60}$ Kube's letter is sometimes interpreted in just the opposite sense; see above all Hilberg, Vernichtung, pp. $371 \mathrm{f}$. Kube wrote: "I personally request from you an official directive regarding the treatment by the civil administration of Jews being deported from Germany to White Russia. Among these Jews are men who fought at the frontline, ... . individuals who are half-Aryan, and even some who are three-fourths Aryan.... These Jews will probably freeze or starve to death in the next few weeks. For us they pose a huge risk of contagion. . . . On my own authority I will not give the SD any order for the treatment of these people [this is referring to the Nazi expression "special treatment," that is, killing] although certain units of the army and of the police have now shown a keen interest in the possessions of these Jews from the Reich. . . . I can be hard, and I stand ready to help solve the Jewish question. But individuals who come from our own cultural milieu are just not the same as the animal hordes from these regions. Do you really want me to have Lithuanians and Latvians slaughter these people? I could not do it. I therefore request, keeping in mind the reputation of the Reich and of our party here, that you issue clear directives indicating the most humane way of accomplishing what is necessary." Kube to Lohse, December 16, 1941, reproduced in facsimile in Max Weinrich, Hitler's Professors (New York, 1946), pp. $153 \mathrm{f}$.

${ }^{61}$ So too in Aly (n. 5 above), pp. 362-67. 
provision in the deportation directives, and he forwarded a written copy to the labor ministry in December. ${ }^{62}$ When Neumann, state secretary for the FourYear Plan, requested confirmation of this arrangement during the conference, Heydrich could thus respond that it was already current practice..$^{63}$ Additional memoranda from Martin Bormann to party officials ${ }^{64}$ and from the Reich Labor Minister to the regional labor offices affirmed the practice in March 1942. ${ }^{65}$

Contrary to Eichmann's expectations, ${ }_{. .}^{66}$ consultations during the Wannsee Conference with State Secretary Josef Buhler from the General Government of Poland also proceeded without conflict. It is possible that Eichmann had not been kept informed about the most recent developments at higher levels. We know that the original invitation list for the conference had not included any representatives from the General Government. Extermination policy in the General Government had not been one of the original topics for the conference, an additional indication that the treatment of German Jews was to be the chief focus. It was only after Heydrich received complaints at the end of November 1941 from Friedrich Wilhelm Kruger, the Higher SS and Police Leader in Krakau, about conflicts with the civilian administration that he directed Eichmann to invite Kruger and the General Governor, Hans Frank. ${ }^{67}$ (Opinions differ about whether or not Kruger actually received an invitation. ${ }^{68} \mathrm{His}$ absence from

${ }^{62}$ Compare Hilberg, Vernichtung, p. 460; memorandum from the Reich Labor Minister to the Regional Labor Offices, December 19, 1941, quoted in Verfolgung, Vertreibung, Vernichtung. Dokumente des faschistischen Antisemitismus, 1933-1942, ed. Kurt Patzold (Frankfurt am Main, 1984), pp. 326 f.

${ }^{63}$ Minutes, fol. 14 (Tuchel, p. 135).

${ }^{64}$ Bormann emphasized that these exceptions were temporary. See memorandum from the head of the NSDAP Party Chancellery 35/42 Re: Employment of Jews in Armaments Plants, March 14, 1942, BA NS 6/337, fols. 68 f.

${ }^{65}$ It appears that the labor ministry "made inquiry" and was informed by the Four-Year Plan Office about the discussion of this issue at the Wannsee Conference. Compare the reference to the "directives currently in force and discussions that recently took place," in Reich Labor Minister Va 5431/1936/42g Circular Re: Workforce, March 27, 1942, To: Regional Labor Offices, Heydrich, and General Georg Thomas (WiRuAmt) (copy), Nuremberg Document L-61.

${ }^{66}$ Interrogation of Adolf Eichmann by his defense counsel, June 26, 1961, in Trial of Adolf Eichmann (n. 25 above), vol. 4, p. 1423.

${ }^{67}$ Notation by Adolf Eichmann, December 1, 1941, reproduced..in Patzold and Schwarz, eds. (n. 23 above), p. 90, facsimile reproduction in Yehoshua Buchler, "A Preparatory Document for the Wannsee 'Conference,'" Holocaust and Genocide Studies 10, no. 1 (1995): 121-27, esp. p. 122. This document had been previously published during the proceedings against Eichmann in Jerusalem, where it appeared as Document No. T/ 182. See Eichmann's remarks on the incident in his interrogation, June 23, 1961, in Trial of Adolf Eichmann, vol. 4, pp. $1421 \mathrm{f}$.

${ }^{68}$ In Adolf Eichmann's letter to Kruger dated December 1., 1941, the invitation formula is absent (Buchler, pp. 123 f.). For an interpretation, see Buchler, p. 126; and Klein (n. 3 above), pp. $13 \mathrm{f}$. 
the meeting may have been due to a broken arm. ${ }^{69}$ ) In a letter dated January 17, 1942, Kruger mentioned that Josef Buhler-who was to attend the conference in Berlin in Frank's place-had paid him a visit on the previous day, during which he discussed a meeting he had arranged with Himmler on the afternoon of January 13. According to Kruger (on the sixteenth), Buhler still seemed "enthusiastic about the reception he had received in [Himmler's] special train." Himmler, in turn, earlier in the morning of that same January 13, had received a report from the commander. of the security police and the SD in the General Government, Eberhard Schongarth. ${ }^{70}$ In view of the timing of all these meetings as well as the lack of controversy at the Wannsee Conference itself, we may reasonably conclude that a basic understanding between Buhler and the SS leadership about liquidating Jews in the General Government, and the lines of authority for it, had already been reached before the conference began. ${ }^{71}$

There were the usual squabbles between the Ministry for the East and SS and police officials: they argued over the definition of who should be treated as a Jew in the occupied Soviet territories, ${ }^{72}$ about authority for Jewish policy, ${ }^{73}$ and about the local pace of the liquidations. For the most part, however, they shared the same elan for extermination. The Ministry for the East had already signaled its basic willingness to accept the plan-namely, that a significant portion of the European Jewish population was to be transported into areas under its control and eliminated there, either by liquidation or by exposure to inhumane living conditions. ${ }^{74}$ Owing to transport problems, to be sure, the plan could not be implemented immediately.

Support for a European-wide "Final Solution of the Jewish Question" was

${ }^{69}$ In a letter to Himmler on January 17, 1942 (BA NS 19/2653, fol. 50), just three days before the date of the conference, Kruger mentioned that his upper arm was in a splint and that he had to spend "hours at forced rest." However, just shortly before this, approximately on January 13, Kruger. apparently traveled to Lublin to meet.Odilo Globocnik. See letter from SS-Hauptsturmfuhrer Max Schuster to SS-Gruppenfuhrer Gottlob Berger, January.27, 1942, BA D-H ZM 1454, A.1, fol. 263.

${ }^{70}$ Kruger to Himmler, January 17, 1942, BA NS 19/2653, fol. 50. Cf. Grothmann, appointment calendar (Grothmann was Himmler's personal adjutant) for January 13, 1942, BA NS 19/3959, with Buhler's request, Himmler, notes of telephone conversations, January 2, 1942, BA NS 19/1439.

${ }^{71}$ After the war, Buhler also mentioned a meeting with Heydrich just prior to the Wannsee Conference. With regard to the content of the meeting, he made patently false statements in an effort to exculpate himself. See report by Josef Buhler, February 19, and interrogation, April 23, 1946, in Patzold and Schwarz, eds., pp. $131 \mathrm{ff} ., 135 \mathrm{ff}$.

${ }^{72}$ The relevant documents can be found in BA R 6/74.

${ }^{73}$ Rosenberg to Lammers, January 8, 1942, and March 25, 1942, with accompanying documents, BA R 43 II/684a, fols. 110-13, 136-47.

${ }^{74}$ Speech by Rosenberg, November 18, 1941, BA NS 8/71, esp. fols. 10, 18. 
also obtained from the Foreign Office without a great deal of persuasion or arm-twisting..$^{75}$ On the contrary, its representative brought to the conference a lengthy list of demands for additional Jewish deportations and for further antisemitic measures throughout Europe. ${ }^{76}$ In November 1941 the foreign ministry had supported the efforts of the RSHA to include in the deportations Romanian, Croatian, and Slovakian Jews living within the Reich. ${ }^{77}$ It had also played a leading role in initiating the murders of Serbian Jews in October $1941 .{ }^{78}$ Even in sensitive cases, with potential international ramifications, the foreign ministry was not opposed in principle to anti-Jewish measures. It intervened only in those instances in which the measures taken were too blatant. For example, the foreign ministry objected to the continued executions of several hundred Jewish hostages from the Netherlands in the concentration camp at Buchenwald after the deaths had attracted international publicity and the attention of Sweden, the Netherlands's protective power. In the end, Himmler acceded and transferred the surviving hostages to S'Hertogenbosch in the middle of November. ${ }^{79}$ But cases involving diplomatic consequences were the exception rather than the rule in the foreign ministry's handling of the "Jewish Question." Certainly the RSHA had to have the foreign ministry's cooperation if the liquidation of the Jews was to be extended to more countries, but this was also

75 The basic study on this subject is Christopher Browning, The Final Solution and the German Foreign Office (New York and London, 1978); see also Hans-Jurgen Doscher, SS und Auswartiges Amt im Dritten Reich: Diplomatie im Schatten der "Endlosung" (Frankfurt am Main and Berlin, 1991).

${ }^{76}$ Notes prepared by Referat D III for Undersecretary of State Luther, in "Re: Suggestions and Ideas from the Foreign Office Regarding the Impending Total Solution of the Jewish Question in Europe," December 8, 1941, reproduced in facsimile in Doscher, SS und Auswartiges Amt, pp. $222 \mathrm{f}$. See also the talking paper prepared by Luther for State Secretary Ernst von Weizsacker (D III 660g, December 4, 1941) with its suggestion to seek a European-wide solution to the Jewish question (Nuremberg Document NG-4667).

${ }^{77}$ The respective governments had already signaled their lack of interest in the fate of their Jewish citizens. See the retrospective note for Joachim von Ribbentrop, April 20, 1943, BA F 72891; Browning, Final Solution, pp. 67 f.

${ }^{78}$ Browning, Final Solution, pp. 55-67.

${ }^{79}$ Reich Fuhrer-SS und Chief of German Police IV D 4 to Lammers, September 30, October 30, and December 5, 1941, BA R 43 II/675a, fols. 107, 114, 117; Browning, Final Solution, p. 69; Seeger (n. 51 above), p. 127. These people had been taken as hostages by the SS after the non-Jewish workers' strike in Amsterdam supporting the Jews in early 1941. The Reich foreign ministry had recommended that a relatively high number of hostage deaths not be reported on any one day. They also recommended that the hostages be returned to the Netherlands since Sweden's role as protective power did not apply to affairs inside the home country. They emphasized that, "In principle the position of the Foreign Office is the same as that of the RSHA and for its part the Office recommends repressive measures against the Jews as instigators [in the sense that they were intellectual instigators of conspiracies]" (D III 588g to Heinrich Muller [RSHA], November 5, 1941, Nurnberg Document NG-3700). 
possible in bilateral negotiations. In general, however, opposition was not to be expected from the Foreign Office.

There remained the question of who was to be treated as Jewish. Beginning in March 1941 various institutions had sought to broaden the concept of "Jewish" as it was applied within the Reich. The Party chancellery, the RSHA, the Racial Policy Office of the National Socialist Party, and the Office of the FourYear Plan wanted to treat the so-called part-Jews of the first degree- that is, half Jews - the same as Jews. ${ }^{80}$ If we can judge by the outcomes of several meetings, the men involved apparently believed by August and September that they were on the verge of having their view implemented throughout Europe. ${ }^{81}$ Hermann Goring's commission to Heydrich had been a factor. On July 31, 1941, Goring had assigned Heydrich "to make all the necessary preparationsorganizational, technical, and material - for a total solution of the Jewish question throughout the German sphere of influence in Europe." 82 Earlier, on July 28 , Goring had declared "that Jews residing in regions under German rule have no further business there." ${ }^{83}$ Apparently neither statement envisioned a liquidation of the entire Jewish population. Rather, Jews were to be "expelled" to the occupied Soviet territories after the successful conclusion of the war. It was foreseen, admittedly, and accepted as a matter of course that there would be an enormous loss of life among the deportees.$^{84}$ Initially, however, the phrase "Final Solution" did not mean an immediate extermination of the Jewish people. It acquired that meaning only later,..especially after the war.

Heydrich proceeded to act on Goring's commission on two fronts. First, he developed plans for deporting Jews from the German Reich to areas in the east while the war was still being fought. Hitler rejected these plans in August. ${ }^{85}$

${ }^{80}$ On the subject of "part Jews," the basic study is Jeremy Noakes, "The Development of Nazi Policy towards the German 'Mischlinge,' 1933-1945,' Leo Baeck Institute Yearbook 34 (1989): 291-354. See also Grenville (n. 54 above); Hilberg, Vernichtung (n. 17 above), pp. 436-49; Adam (n. 18 above), pp. 316-33.

${ }^{81}$ Noakes, pp. 338-41; Adam, pp. 319 f.; Burrin (n. 5 above), pp. 136 f.

${ }^{82}$ Goring's commission to Heydrich, July 31, 1941, contemporary photocopy (with accompanying letter to State Secretary Karl-Hermann Frank, Prague, January 25, 1942), BA D-H M 501, A.3, fols. 4, 7, reproduced in Patzold and Schwarz, eds. (n. 23 above), p. 79.

${ }^{83}$ Communications Office of Armed Forces High Command, Economics and Armaments Office at the Reich Marshall, to General Georg Thomas, July 29, 1941, BA-MA (BArchP) F 44544, fol. 104.

${ }^{84}$ See, e.g., Aly, pp. $306 \mathrm{f}$.

${ }^{85}$ Compare Witte (n. 16 above), pp. 318 ff.; Broszat (n. 29 above), p. 750. On August 7, the RSHA completed its first estimate of the number of Jews living in Europe. Number of Jews, Absolutely and as a Percentage of Population, in the Countries and Regions of Europe, August 7, 1941, Archiwum Glownej Komisji Gadania Zbrodni przeciwko Narodowi Polskiemu, Warschau, CA 362/218, fols. 5-10. The exhibit was presumably prepared by Eichmann. 
Second, Heydrich's office used the authority conferred by Goring's commission as a basis for justifying "in particular" its efforts to widen the defined meaning of the term "Jew." 86 This effort seemed to meet with some success. The chief of the Reich chancellery, Hans-Heinrich Lammers, supported it, as did the party chancellery, the Fuhrer chancellery, and the Army High Command. ${ }^{87}$ They all wanted some new regulation that would reduce the thousands of requests and petitions for exceptions in special cases that had to be processed and forwarded to Hitler. ${ }^{88}$ Of all the government ministries, only the interior ministry stood opposed.$^{89}$ We can see this in the document prepared by State Secretary Wilhelm Stuckart's adviser on Jewish affairs, Losener, for Stuckart's use at the Wannsee Conference on its initially scheduled date. ${ }^{90}$ But both Hitler and Goring seem to have objected to the proposed changes in the status of the "part-Jews of the first degree." ${ }^{91}$ Exactly what Hitler thought about Jews who were married to non-Jewish Germans, in particular on the issue of

${ }^{86}$ Notation by an official in the Reich Commissariat of the Netherlands, September 19, 1941, regarding a conversation with Bernhard Losener on September 16, 1941, IfZ, Eichmann Trial Document 1355.

${ }^{87}$ Noakes, pp. 341 f.; Adam, pp. 320 f.; notations by Erhard Wetzel and Walter Labs (both of the Ministry for the East), October 27, 1941, and January 16, 1942, BA R 6/74, fols. $24 \mathrm{f}$. and 54R. For a positive (and thus, in my view, unsupported) evaluation of the positions taken by Lammers and the Reich chancellery in regard to Jewish policy, see Dieter Rebentisch, Fuhrerstaat und Verwaltung im Zweiten Weltkrieg (Stuttgart, 1989), pp. 434-41.

${ }^{88}$ According to the First Ordinance of the Reich Citizenship Law, November 14, 1935, Hitler had the power to grant exceptions to the provisions regulating the definition of Jews and part-Jews. See Adler (n. 46 above), p. 280. On the large number of special requests, see Adam, pp. 301 f.; and the file BA $62 \mathrm{Ka} \mathrm{1,} \mathrm{Nr.} 63$.

${ }^{89}$ See, in particular, Losener, "Rassereferent" (n. 42 above), esp. pp. 296 ff. Although this postwar memoir contains elements of self-justification, it agrees for the most part with the files of 1941/42, insofar as these have survived. See also Noakes, pp. $353 \mathrm{f}$. There must remain some doubt, however, as regards the genuineness of documents cited by Losener that no longer exist.

${ }^{90}$ Notation by Bernhard Losener, December 4, 1941, with two accompanying documents, BA R 18/5519, fols. 477, 483-95.

${ }^{91}$ Noakes (n. 80 above), pp. 353 f.; notation by an official of the Reich.Commissariat of the Netherlands, September 19, 1941, concerning a discussion with Losener on September 16, IfZ, Eichmann Trial Document 1355; notation by Losener, August 18, 1941, concerning a report by Kritzinger (Reich Chancellery) and outline by Losener of a Stuckart memo, August 21, 1941 (accompanied by the notation that..Heydrich had purportedly communicated Hitler's contrary opinion to Rosenberg), in Losener, "Rassereferent," pp. 304, 306. The claim made by Adam, p. 321 (cf. p. 330) that at the Wannsee Conference Heydrich put forward a position that had been approved by Hitler is speculation. With regard to the eleventh ordinance, Hitler had rejected the more far-reaching first drafts. Initially, the Reich interior ministry and the Reich justice ministry had sought to deprive German Jews generally of their German citizenship. See R 18/5519 and R 43 II/ 136a, esp. a notation by Lammers, May 29, and Lammers's note to Wilhelm Frick, Schlegelberger, and Bormann, June 7, 1941, fols. 122-124R. 
compulsory divorces, remains unclear. ${ }^{92}$ We do know that he wanted to limit the number of exceptions granting preferential treatment to Jews in special cases. ${ }^{93}$ But apparently he did not make any official decision, except with regard to the "part-Jews of the second degree" (so-called Quarter-Jews), and for this group he preliminarily refused to approve a reduction in citizenship status. ${ }^{94}$ The rather vague reports of his comments on December 1 or December 2 seem to confirm these leanings. ${ }^{95}$ It should be noted that Hitler's misgivings, like those at the interior ministry, were political rather than moral. Part-Jews and Jewish spouses in mixed marriages had too many non-Jewish relatives and friends. Treating them more harshly could cause too much unrest.

The RSHA hoped that the Wannsee Conference would produce a breakthrough. In mid-December, Dr. Walter Labs, counselor in the Reich Ministry for the East, received an oral report from Dr. Werner Feldscher, an adviser in the Reich interior ministry:

As for the proposed changes in the definition of the term "Jew," Dr. Feldscher gave me the following information. With the approval of the Fuhrer, the Reich Marshall [Goring] commissioned SS-Obergruppenfuhrer Heyderich [sic] to make preparations for carrying out an immediate and unified solution of the Jewish question in Europe after the conclusion of the war. In fulfilling this assignment Heyderich scheduled a meeting of the state secretaries from the relevant ministries. Due to the session of the Reichstag, the meeting had to be postponed until January. At the meeting, Heyderich intended to discuss the desire of the RSHA to expand the definition of the term "Jew" in order to include part-Jews of the first degree and to mete out harsher treatment to part-Jews of the second degree. Heyderich planned to..use the results of the meeting as a basis for his presentation to the Reich Marshall [Goring] or to the Fuhrer and for his proposal to amend the Nuremberg laws for Germany. ${ }^{96}$

${ }^{92}$ According to an unsigned note, outcome of a meeting in the main office of the Security Police, in "Re the Solution of the Jewish Question in Europe" (undated; presumably the author was Dr. Werner Feldscher), Hitler rejected the idea. See BA R 18/5519, fol. 485; see also Lammers to Finanzminister Lutz Graf Schwerin von Krosigk, June 19, 1941, BA 7.01, Nr. 4112, fol. 270.

${ }^{93}$ Lammers to Schwerin v. Krosigk, February 17, 1942, regarding a statement made by Hitler in July 1941, BA 7.01, Nr. 4112, fol. 284.

${ }^{94}$ Agitated, Hitler had insisted that any ultimate decision on this issue would be made by him. See Lammers to R. Walther Darre, April 10, 1941, BA R 43 II/598, fol. 60/R; Noakes, p. 340 (September 1941).

${ }^{95}$ As far as can be ascertained, he expressed himself in relatively positive terms about individuals in so-called mixed marriages and about "second and third generation partJews." He spoke positively about the existing racial laws but opposed the granting of exceptions. See Jochmann, ed. (n. 31 above), pp. 147-49.

${ }^{96}$ Recorded in a confidential note by Walter Labs, hand-dated, January 16, 1942, BA R $6 / 74$, fol. 54; emphasis added. Labs was section chief for general administration in the Ministry for the East. Aly and Heim (n. 5 above), p. 469, brought this document to the attention of scholars. 
As late as August 1941, the interior ministry had laid claim to "responsibility for the Jewish question" and had received formal acceptance of this from other Reich offices. ${ }^{97}$ But on November 24, during a conversation with Stuckart, Himmler disputed this authority, noting "Jew question—belong [sic] to me." 98 The exact content and course of this conversation cannot be clearly determined. In particular, we do not know whether Himmler merely claimed to have authority or whether Stuckart agreed with him. On December 21, Stuckart observed that "more and more, leadership on the Jewish question has slipped away from the interior ministry." He no longer would, or perhaps could, do anything to prevent the mass executions of German Jews, such as the one in Riga. ${ }^{99}$

During the intervening period, something significant must have occurred. It is my belief that the discussions taking place among the central offices of the Reich were overtaken in early December 1941 by Hitler's announcement of his fundamental political decision. This new turn of events meant that the Wannsee Conference would eventually convene in a context quite different from the one that had prevailed when Heydrich had originally planned the meeting.

\section{Hitler's Announcement of the Decision to Exterminate All European Jews}

Himmler and Hitler met on the afternoon of December 18, 1941. In regard to the first topic discussed, Himmler recorded, "Jewish question | to be exterminated as partisans." ${ }^{100}$ There can be no doubt that what Himmler wrote down after the vertical line represented the results of the conversation. But what did the brief notation mean? Linguistically, the statement is an order. The term "partisans" may at first glance seem to suggest the situation in the Soviet Union, but the execution of Soviet Jews had been decided some time ago and was already under way. Further, at that point there was not yet a significant number of Jewish partisans in the occupied Soviet territories. These considera-

${ }^{97}$ Note by Losener, August 17, with note by Acting State Secretary Pfundtner, August 20, 1941, and the notation, "The Minister has approved this.note," in BA R 18/3746a, published in Losener, "Rassereferent," p. 303; notation by Losener about a meeting in the Propaganda Ministry, August 15, 1941, in "Rassereferent," p. 301 (statements by the Four-Year Plan Office and by the propaganda ministry).

${ }^{98}$ Himmler, meeting notes, November 24, 1941, Sonderarchiv Moskau 1372-5-23, fol. 360 .

${ }^{99}$ Losener, "Rassereferent" (n. 42 above), p. 311.

${ }^{100}$ Meeting notes, "Meeting with the Fuhrer at Wolfsschanze, December 18, 1941, 4 PM, Fuhrer," Himmler, appointment calendar (n. 30 above), fol. 334. A published version of this source, with commentary, is in preparation. To the knowledgeable discussions of its editorial group I owe a deeper insight into the structures of the decision-making process that led to the extermination of European Jews. 
tions suggest that Himmler's notation meant something else-that it referred to potential partisans and to the supposed "Jewish threat." It is significant that Himmler's note lists the topic of conversation not as "Jews in the east" or as "Soviet Jews" but rather as the all-encompassing "Jewish question." By itself, Himmler's notation is difficult to interpret unambiguously, but there is some justification for interpreting Hitler's statement in a global sense.

Himmler's notation may be read in connection with other documents that help shed some light on its meaning. One of these documents is a letter to Himmler written on June 23, 1942, by Viktor Brack, the person responsible for the Euthanasia Program. In the letter, he explained that he had again placed some of his staff at the disposal of Odilo Globocnik ${ }^{101}$ for his use at extermination camps connected with "Operation Reinhard"- the code name for the program to liquidate Jews from the General Government in the camps at Belzec, Sobibor, Treblinka, and Majdanek: "Brigade Leader Globocnik took the opportunity to express his opinion that this action against the Jews should be carried out as quickly as possible, so that it not be left unfinished should any difficulties make it necessary to suspend the operation. At one time, you yourself, Reichsfuhrer, indicated to me [in person] that for reasons of secrecy we ought to complete the work as quickly as possible." ${ }^{102}$

Evidence in this same letter suggests that Brack was referring to the decision to execute Jews from throughout Europe, for he remarks that out of "approximately ten million European Jews" it would be better to "preserve" than to liquidate "two or three million of them," in order to use them as a labor supply for the German war economy. The excerpt cited above occurs in the same context. Furthermore, in my opinion, the wording of the last sentence in that excerpt suggests that Brack can only be referring to a personal conversation with Himmler that had taken place some time ago ("at one time"). According to Himmler's appointment schedule for 1941 and 1942 (a rather substantial set of documents), the most recent meeting between Himmler and Brack before this letter occurred on December 14, 1941. Topics of discussion were listed as "[ ... ] Course in East Minist[ry]" and "Euthanasia." ${ }^{103}$ In light of this chain

${ }^{101}$ Odilo Globocnik was SS- and Police Leader in the Lublin district of the Government General from 1939 to 1943.

102 "Bei dieser Gelegenheit vertrat Brigadefuhrer Globocnik die Auffassung, die ganze Judenaktion so schnell wie nur irgend moglich durchzufuhren, damit man nicht eines Tages mitten drin steckenbliebe, wenn irgendwelche Schwierigkeiten ein Abstoppen der Aktion notwendig machen. Sie selbst, Reichsfuhrer, haben mir gegenuber seinerzeit schon die Meinung.geaußert, daß man schon aus Grunden der Tarnung so schnell wie moglich arbeiten musse.” Viktor Brack to Himmler, June 23, 1942, BA NS 19/1583, fol. 34; emphasis added.

${ }^{103}$ Compare Sonderarchiv Moskau 1372-5-23, esp. fol. 341 (the first short or incomplete word is indecipherable); Grothmann (n. 70 above). The surviving correspondence between Himmler and Brack mentions no other meeting between them during this period. 
of evidence, it seems highly likely that Himmler discussed the plans to liquidate all European Jews with Brack at that meeting.

Further, Philipp Bouhler, the head of the Fuhrer Chancellery and Brack's superior, was present on December 13, 1941, at a meeting with Hitler attended by Rosenberg and von Ribbentrop. He was also present at a December 14, 1941, meeting with Hitler that Himmler and Rosenberg attended. ${ }^{104}$ The frequency of these meetings is striking. According to his letter cited above, Brack, at Bouhler's behest, had provided personnel to Globocnik on at least two occasions for use at the extermination camps. After the war Brack would testify that this had first occurred following a meeting between Himmler and Bouhler. ${ }^{105} \mathrm{~A}$ document written by Bouhler in July 1942 confirms this last point, especially Bouhler's own responsibility: he asserts that "I have placed a large part of my organization at the disposal of Reichsfuhrer Himmler for use in a solution to the Jewish question that will extend to the ultimate possible consequences." ${ }^{106}$

As to exactly when the first large group of personnel from the Fuhrer chancellery arrived in Belzec, there are conflicting opinions as to whether it was in November or December of $1941 .{ }^{107}$ Based on all the available evidence, it seems to have been shortly before the Christmas of $1941 .{ }^{108}$ It is possible that the exchanges on December 13 and 14 described above led to a shift of personnel on very short notice. But it is also conceivable that, at these meetings, Bouhler, Rosenberg, and Himmler gave Hitler only information about the steps

${ }^{104}$ Jochmann, ed., pp. 150, 152.

${ }^{105}$ Brack to Himmler; "Sworn Statement of Viktor Brack," October 12, 1946, Nuremberg Document NO-426.

106 "Anders ware ja nicht zu verstehen, wenn ich einen großen Teil der mir unterstehenden Organisationen dem Reichsfuhrer zu einer bis in die letzte Konsequenz gehenden Endlosung der Judenfrage zur Verfugung gestellt habe.” Philipp Bouhler to Bormann, July 10, 1942, BA 62 Ka 1, Nr. 83, fol. 109; emphasis added.

${ }^{107}$ According to Arad, Belzec, Sobibor, Treblinka (n. 13 above), p. 17, it was in 1941, between the end of October and the end of December. It was somewhat later according to Michael Tregenza, "Belzec Death Camp," Wiener Library Bulletin 30 (1977): 8-25, esp. pp. 14-16. According to the account by Eugen Kogon et al. in Nationalsozialistische Massentotungen durch Giftgas (Frankfurt am Main, 1983), pp. 153 f., Christian Wirth, a member of the Fuhrer chancellery, became commandant of Belzec in the latter half of December. When he arrived there was already snow on the.ground. Pohl, Lublin (n. 4 above), p. 105 (cf. p. 101) claims that personnel from the Fuhrer chancellery arrived in November 1941, but he makes erroneous use of statements by Tregenza and Kogon et al. Only Josef Oberhauser and two other individuals were sent as early as September 1941, but that seems to have been for other purposes.

${ }^{108}$ See interrogation of Josef Oberhauser, December 14, 1962, in Ernst Kleee, Willi Dressen, and Volker Riess, eds., "Schone Zeiten": Judenmord aus Sicht der Tater und Gaffer, 2d ed. (Frankfurt am Main, 1988), p. 208. The Polish laborers were discharged on December 22, 1941, when the barracks construction was complete. See interrogation of Stanislaw Kozak, in Kogon et al., pp. $152 \mathrm{f}$. 
that had already been taken to exterminate the Jews using poison gas - that is, about the murders using gas vans in the Soviet territories and in Chelmno, and about the status of preparations at Belzec. The meetings may also have led to "experts" being sent to the planned extermination sites in order to inspect the liquidation techniques. ${ }^{109}$ At the very least, it is difficult to believe that these meetings had no connection at all with the unfolding of the "Final Solution."

What brought about this sudden flurry of meetings? The reason can be seen most clearly in a note made by Rosenberg on December 16, 1941. The entry deals with a meeting Rosenberg had had with Hitler two days earlier. At that meeting, Rosenberg gave Hitler the manuscript copy of a speech for the Fuhrer's approval. Hitler "remarked that the text had been prepared before the Japanese declaration of war, in circumstances that had now altered." Rosenberg's entry continues as follows: "With regard to the Jewish question, I said that my remarks about the New York Jews would perhaps have to be changed now, after the decision. My pọsition was that the extermination of the Jews should not be mentioned. The Fuhrer agreed. He said they had brought the war down on us, they had started all the destruction, so it should come as no surprise if they became its first victims." 110

By "the decision" Rosenberg could not have meant the entry of the United States into the war, for there is no logical connection between that event and the cessation of public threats against the Jews. ${ }^{111}$ Hitler's reaction indicates

${ }^{109}$ It is possible that Heydrich sent Eichmann to Belzec at this time (see n. 146). One of the "experts" who may have been sent was August B.ecker, a technician in charge of the gas vans. He said that he was transferred from the Fuhrer Chancellery to the RSHA following a conversation between Himmler and Brack, and then sent on to Riga. Becker stated later that he was involved in an accident in Deutsch-Eylau (East Prussia) on his way to an inspection in Riga on December 14, 1941, but his recollection may be mistaken by several days; he said he came out of the hospital before Christmas. See interrogation of August Becker, March 26, 1960, in Klee, Dreessen, and Riess, eds., p. 71. The exact date of Becker's accident is apparently no longer documented, and it was never checked by any historian or juridical institution at the Wehrmachtauskunftsstelle Berlin, which is in charge of this matter. Information from the Wehrmachtauskunftsstelle Berlin, December 1997. If this general interpretation is correct, it is a further indication that the RSHA first had to gather information about the status of regional planning for extermination efforts.

${ }^{110}$ Notes on a discussion with the Fuhrer, December 14, 1941, prepared by Rosenberg on December 16, 1941, BDC, SL 47F (copy), published as Nuremberg Document PS1517 in IMT, vol. 27, p. 270; emphasis added. Hartog (n. 6 above), p. 71, also draws attention to this passage, connecting its essential elements with Hans Frank's speech in Krakow on December 16, 1941 (see below), and with Hitler's January 30, 1939, prophecy that another world war would lead to the extermination of the Jews in Europe.

${ }^{111}$ This is what Rosenberg maintained during his interrogation, April 17, 1946, IMT, vol. 11, pp. 606-8, though he could not explain why that meant that further threats against the Jews should not be made in public. The words "now, after the decision" (jetzt nach der Entscheidung) were not investigated further by the court, since the court believed that any such decision would have been made considerably earlier. 
this as well, for he reiterates the justification for his decision to exterminate the Jews. Rosenberg certainly would have been informed immediately about such a decision, so this discussion on December 14 about the need to alter a speech that Rosenberg had written before December 7 indicates that the decision to "exterminate the Jews in Europe" must have been made after December 7 and before December 14, 1941. ${ }^{112}$

It is well known that Hitler, in an infamous speech to the Reichstag on January 30, 1939, had spoken as follows: "If the world of international financial Jewry, both in and outside of Europe, should succeed in plunging the nations into another world war, the result will not be the Bolshevization of the world and thus a victory for Judaism. The result will be the extermination of the Jewish race in Europe." ${ }^{113}$ Hitler announced his declaration of war against the United States in the Reichstag on December 11, 1941. For Germany, that made the war a world war. ${ }^{114}$ Thus the situation Hitler had envisioned in 1939 had come about. With complete logical consistency — consistent within the framework of his antisemitic worldview-Hitler then proclaimed his decision to exterminate all Jews in Europe. He did not, to be sure, include this announcement in his Reichstag speech of December 11, a speech broadcast on radio. In that speech he claimed only that Jewish war agitators were behind Roosevelt. ${ }^{115}$ But on the following afternoon, December 12, 1941, Hitler addressed a meeting of the most important sectional leaders of the National Socialist Party (the Reichsleiter) and of regional party leaders (the Gauleiter). ${ }^{116}$ According to

${ }^{112}$ The manuscript of the speech still exists, apparently in a version prepared after the discussion with Hitler. (The first version was prepared before the Japanese attack on Pearl Harbor, and this version includes a reference to that attack.) In it, Rosenberg threatened the "New York Jews" in response to their supposed "world-wide agitation against Germany and associated policy of military encirclement" with "corresponding German measures against the Jews living in the east." "For in the eastern territories currently under the control of German armed forces, there are more than 6 million Jewish inhabitants. For more than a hundred years, eastern Jewry has been the source and spring of Jewish power throughout the world." Rosenberg talked about "destroying the springs from which the New York Jews had drawn their powers," and about "a negative elimination of these parasitic elements." See "The Great Moment of the East. Speech by Reichsleiter Rosenberg in the Sports Palace," December 18, 1941, BA R 6/37, fols. 31 ff., esp. fols. 47-49.

${ }^{113}$ See Hitler's speech for the session of January 30, 1939, in Verhandlung des Reichstages, 4th Wahlperiode, 1939, vol. 460. Stenographic Reports, 1939-1942. Photocopy Bad Feilnbach 1986, p. 16; emphasis added.

${ }^{114}$ Similarly Hermann Goring, Reichstag Session, December 11, 1941, ibid., p. 106.

${ }^{115}$ Ibid., pp. 93-106. The speech was supposed to be broadcast live outside Germany as well. See Elke Frohlich, ed., Die Tagebucher von Joseph Goebbels, pt. II, vol. 2 (Munich, 1996), p. 476 (for December 11, 1941).

${ }^{116}$ On the invitations dated December 9, 1941, the meeting was scheduled for December 10. Later on December 9, the meeting was rescheduled for December 11 and then obviously postponed once again. See two teletype messages from the Party chancellery 
Goebbels's notes on this meeting of the Reichsleiter and Gauleiter, Hitler spoke as follows:

Regarding the Jewish question, the Fuhrer is determined to clear the table. He warned the Jews that if they were to cause another world war, it would lead to their own destruction. Those were not empty words. Now the world war has come. The destruction of the Jews must be its necessary consequence. We cannot be sentimental about it. It is not for us to feel sympathy for the Jews. We should have sympathy rather with our own German people. If the German people have to sacrifice 160,000 victims in yet another campaign in the east, then those responsible for this bloody conflict will have to pay for it with their lives. ${ }^{117}$

There were other occasions, too, both before and after December 1941, when Hitler made reference to his infamous "prophecy." But he never before did so as clearly, as unambiguously, or in such a matter-of-fact way as recorded here by Goebbels. ${ }^{118}$ What Hitler said was not intended metaphorically or as propaganda-that is the meaning of Goebbels's phrase, "Those were not empty words." Above all, Hitler had now spoken of the beginning of total annihilation. He had made his remarks before a group of listeners outside his most inner circle of confidants. It was the leadership of the party that was assembled together. Because attendance at such meetings was mandatory, we can be virtually certain about which individuals were present: Himmler, Martin Bormann, Rosenberg, Hans Frank; Arthur Greiser, Fritz Bracht, and Fritz Sauckel (the Gauleiter in Warthegau, in Upper Silesia, and in Thuringia, respectively); Hinrich Lohse and Erich Koch (the Reich commissars for the Ostland and for the Ukraine, respectively); Alfred Meyer, Goebbels, and Philipp Bouhler. ${ }^{119}$ These

of the NSDAP, December 9, 1941 (Martin Bormann, 10:45 A.M.; Friedrichs, 3:45 P.M.), BA NS 8/186. I am indebted to Armin Nolzen for this reference.

${ }_{117}$ Goebbels, Tagebucher, pt. 2, vol. 2, pp. 498 f. (see entry for December 13, 1941).

${ }^{118}$ Breitman (n. 5 above), p. 155 (January 30, 1941); Broszat (n. 29 above), pp. 749 f. (August 18, 1941, based on Goebbels's record); Jochmann, ed., p. 106 (October 25, 1941); Adam (n. 18 above), p. 316 (January 30, 1942); quite clearly in his speech on February 24, 1942 (excerpts published in Patzold, ed., pp. 345 ff.).

${ }^{119}$ Rosenberg and Frank were Reichsleiter; Lohse was Gauleiter in SchleswigHolstein; Koch was Gauleiter in East Prussia; Goebbels was Gauleiter in Berlin; Meyer was Gauleiter in Westphalia. It has been documented that Greiser, Frank, and Lohse were in the Reich, or in Berlin. We have already discussed Himmler, Rosenberg, and Bouhler; see also Himmler, appointment calendar, fol. 343. See also Schlegelberger to Greiser, December 15, 1941, BA R 22/850, fols. 215R-216 (on December 10, Franz Schlegelberger called Greiser in Berlin). For Lohse, see Goring, appointment calendar, December 8, 19.41, IfZ ED 180/5 (I am indebted to Christoph Dieckmann for this reference). Werner Prag and Wolfgang Jacobmeyer, eds., Das Diensttagebuch des deutschen Generalgouverneurs in Polen 1939-1945 (Stuttgart, 1975), p. 449. Wilhelm Kube still held the formal title of Gauleiter but was no longer active as one, and thus he was not invited to the meeting of the Reichsleiter and Gauleiter. I am grateful to Armin Nolzen for this information. 
were the decisive political figures involved in the destruction of the Jews in Europe. They were also the administrative heads of all the regions containing the centers where, both then and subsequently, Jews were exterminated. Hermann Goring was not present. He held no party office that would have required his attendance at the meeting. It is probable, too, that Reinhard Heydrich was not in attendance. ${ }^{120}$

Several tightly woven elements contributed to the reasoning behind Hitler's decision and the timing of its announcement. The first was retribution for the supposed anti-German activities of "World Jewry" and the alleged responsibility of the Jews for the war, recalling his 1939 "prophecy." In the intervening years he had repeated his threat on numerous occasions, some of them public, thus emphasizing its importance. In Hitler's nationalistic perspective, all German claims to preeminence were justified. At the same time, his antisemitism caused him to view any opposition to these claims as stemming from a Jewish conspiracy. Thus his "prophecy" was of necessity a self-fulfilling one. Second, the entry of the United States into the war gave him a welcome pretext to announce a decision that he and others presumably had been contemplating in any case. A third consideration could have been that the European Jews had lost, for the Nazi leadership, their role as hostages who might deter the United States from an open entry into the war. ${ }^{121}$ The war situation entered into Hitler's rationalization in yet another way, for it created, in the fourth place, a kind of European fortress mentality among the Germans. The new prospect of a second front, combined with the military defeat in the Battle of Moscow, had created a rather serious situation for the German leaders. ${ }^{122}$ Within this more threatening context, Hitler viewed the Jews as opponents, revolutionaries, saboteurs, spies, "partisans" in his own backyard—an area that now, in light of

This explains why Kube had to write for information in his letter of December 16, 1941, cited above in n. 59 .

${ }^{120}$ At the same hour Goring was scheduled to meet with Keitel and with General Osterkamp, the head of the army administrative office, at his Carinhall estate. See Goring, appointment calendar, December 12, 1941, IfZ ED 180/5. On December 9, however, Goring had spoken at length with Hitler (ibid.). For Heydrich, see his report to Bormann, December 30, 1941, which suggests that he was in Prague on. December 12, 1941; see Miroslav Karny et al., eds., Deutsche Politik im "Protektorat Bohmen und Mahren” unter Reinhard Heydrich 1941-1942 (Berlin, 1997), p. 205.

${ }^{121}$ This consideration is emphasized by Hartog (n. 6 above), esp. pp. $11 \mathrm{ff} ., 75 \mathrm{ff}$.

${ }^{122}$ In view of the dates, and of the whole fabric of rationalizations, it cannot be maintained that Hitler decided to exterminate the Jews in the euphoria of victory or because he thought he was invincible. This position has been put forward by Christopher Browning in "The Euphoria of Victory and the Final Solution: Summer-Fall 1941," German Studies Review 17,no. 3 (1994): 473-81. See also Andreas Hillgruber, Hitlers Strategie: Politik und Kriegfuhrung 1940-1941 (Frankfurt am Main, 1965), pp. 524 f. 
the expected United States attack, included all of Europe. That was what Hitler had meant by his remark, recorded by Himmler on December 18, 1941, "to be exterminated as partisans." ${ }^{23}$ Heydrich's perspective on the geopolitical situation was very similar. This can be seen clearly in a speech he delivered on December 17 in which he observed that Hitler's speech to the Reichstag and Japan's attack on the United States had created "a perfectly clear situation in the world. The forces of Judaism, of Bolshevism, of unscrupulous profit, and of egoism are ranged together in opposition to a united Europe." ${ }^{124}$ Alfred Rosenberg, too, viewed the Jews as troublemakers. ${ }^{125}$ Toward the end of 1943, Himmler employed the same "argument" when he noted that the aerial bombardments, the attacks by partisans, and the retreats at the front lines might have led to a collapse of German resistance if the Jews had still been present as an "element of uncertainty" - in other words, if the Germans had not already destroyed them. ${ }^{126}$ By "removing" the Jews, Hitler himself was to assert in a secret address on May 26, 1944, he had "prevented the formation of any possible revolutionary kernels or cells." The matter could not "have been handled more humanely" since Germany was "in a fight to the death." 127

The context in which Hitler announced his decision is itself revealing. The announcement was made not in the most inner circle, not informally in a confidential conversation with Himmler, and not within the narrow confines of his

${ }^{123}$ See n. 100. Apparently Himmler made the notation because he considered this the most important result of the discussion. Hitler repeated the phrase often in his justifications. See in addition his conversation with Goebbels the previous day (Goebbels, Tagebucher, pp. 533 ff., for December 18, 1941). In fact, the meeting with Himmler probably concerned some concrete arrangement, unknown to us, for implementing the Jewish extermination.

${ }^{124}$ Reinhard Heydrich, ".Die Wirtschaft als massgeblicher Faktor der staatlichen und politischen Neuordnung Bohmens und Mahrens im Reich," in Tagung der SudosteuropaGesellschaft und der Deutschen Gesellschaft der Wirtschaft in Bohmen und Mahren (Berlin, Prague, Vienna, 1942), p. 11 (BA R 63/279). On the question of the dating, see Heydrich's report to Bormann, December 30, 1941, and see Karny et al., eds., p. 205.

${ }^{125}$ On the same day, Rosenberg sent Hitler a letter suggesting that Jewish leaders being held in France as hostages should be shot, because worldwide Jewry was responsible for the assassination attempts and the agitation actions of the French communists. (See Rosenberg to Hitler, December 18, 1941, in Patzold and Schwarz, eds., pp. 96 f.) Hitler's reaction to the letter was positive, at least in part. See Lammers to Rosenberg, December 31, 1941, BA R 43 II/1444, fol. 56.

${ }^{126}$ Himmler, speech at the meeting of SS-Group Leaders, October 4, 1943, IMT, vol. 29, pp. 145 f.; for additional examples, see Bradley F. Smith and Agnes F. Peterson, eds., Heinrich Himmler: Geheimreden, 1933-1945 (Frankfurt am Main, 1974), pp. 169, 200-5.

${ }^{127}$ Hitler, speech to generals and officers at Platterhof, May 26, 1944, IfZ, MA 316, fol. 5022 , cited in Broszat, p. 759, who makes the connection between this address and the crisis in the winter of 1941-42. 
close circle of advisers, Goring, Heydrich, and Bormann. ${ }^{128}$ Nor was it a meeting of government officials, though some of the men present did hold such posts. Rather, the announcement was made before an official body that included his oldest and closest political comrades; some fifty people were present. His message was this: the destruction of the Jews was first and foremost a party matter. Subsequent events would confirm the party's special role, in particular with regard to the extermination of German Jews. ${ }^{129}$ Some of those present at the announcement had already urged Hitler to take harsher steps against the Jews. These included such men as Joseph Goebbels; Karl Kaufmann; Baldur v. Schirach, who had been involved in the decision to deport the German Jews; ${ }^{130}$ and Martin Mutschmann, who had even urged, possibly in that very fall of 1941, that Jews be executed. ${ }^{131}$ Gauleiter Carl Rover personally signed the deportation order for each and every Jewish citizen transported from Bremen. ${ }^{132}$ Lohse had himself been present at an execution two weeks earlier, as noted above. So there was no one in this audience who needed to be converted. Formally, Hitler was not giving an order; he was simply announcing a decision. One thing more about the meeting should be noted. Meetings of the Reichsleiter and the Gauleiter were normally held in the conference rooms of the New Chancellery or in one of the party buildings. For this meeting, however, despite the official occasion, the setting was a private one, in Hitler's residence. ${ }^{133}$

${ }^{128}$ This suspicion was expressed by Hartog, p. 65 . One cannot rule out the possibility that there may have been one or more meetings on the subject. It would be very difficult to prove that there were not (see n. 144). But if it truly is the case that Heydrich first learned about the announcement of the decision from Himmler, then the occurrence of any such meetings is less likely.

${ }^{129}$ See Sec. V. The important role of the Fuhrer Chancellery in "Operation Reinhard" should also be kept in mind. Further, the Lublin SS- and Police Leader, Odilo Globocnik, who became the leader of "Operation Reinhard," had himself at one time been a Gauleiter.

${ }^{130}$ See .Witte (n. 16 above), pp. 318 ff.; Frank Bajohr, "Gauleiter in Hamburg. Zur Person und Tatigkeit Karl Kaufmanns," VfZ 43 (1995): 267-95, esp. pp. 291 f.

${ }^{131}$ From the Reichsstaatshalter in Saxony (Martin Mutschmann) to Himmler, July 25, 1944, BA NS 19/1872, fols. 1 f. According to Mutschmann, he had already brought up the "argument" mentioned earlier, namely, that Jews would turn into partisans and create disorder behind the frontlines. This suggests that he had raised the idea between June and December of 1941. Prior to June 1941 there would have been no reason for such a position. After December 12, 1941, the suggestion would have become superfluous. In February 1940 Mutschmann had demanded the wearing of the Jewish star; see Losener (n. 42 above), p. 302.

${ }^{132}$ Gunther Rodenburg, "Die letzten 26 Tage in Bremen," in Es geht tatsachlich nach Minsk, ed. Rodenburg and Andreas Ropcke (Bremen, 1992), pp. 7-20, esp. p. 9.

${ }^{133}$ See Himmler, Appointment Calendar (n. 30 above). These were Hitler's private rooms in the Old Reich Chancellery, rooms that normally were not used for official meet- 
In such a circle of listeners, the quoted passage from Hitler's address had the effect of a directive. Other documents in addition to the Rosenberg.passage cited earlier are indicative of this. On December 18, 1941, Dr. Otto Brautigam, the section chief for general politics in the Ministry for the East, wrote to Lohse concerning the issue of whether exceptions should be made for workers when Jews were to be executed:

As for the Jewish question, oral discussions that have taken place in the meantime have brought about clarification. As a general rule, economic factors should not be considered in deciding the matter. In the future, any questions that may arise should be settled directly with the Upper SS and Police Leader. ${ }^{134}$

Brautigam was thus aware from various conversations that were now taking place that a new situation had arisen following Hitler's speech on December 12. Most probably, however, he had not been informed of the exact course of events at the higher levels, an indication of the fact that the proceedings at the meeting of the Reichsleiter and Gauleiter were being treated as strictly confidential. ${ }^{135}$ Lohse himself later said that Hitler's address to the Reichsleiter and Gauleiter was confidential and as a general policy the participants at such meetings were not to discuss them. ${ }^{136}$ Further, the ministry guidelines communicated by Brautigam did not signify that all Jews were to be executed immediately. The ministry guideline provided merely the general line. ${ }^{137}$ This is impor-

ings such as this. Hitler thus announced his decision just twelve days before he put a final stop, at least according to David Irving, to the extermination of the Jews.

${ }^{134}$ Brautigam to Lohse, December 18, 1941, facsimile reproduction in Weinreich, p. 156; emphasis added.

..${ }^{135}$ According to his interrogation, November 19, 1948, Staatsanwaltschaft NurnbergFurth 72 Ks 3/50a-b, vol. 1, fol. 53R (in the Bayerisches Staatsarchiv in Nuremberg) Otto Brautigam was referring to a discussion between Rosenberg or Alfred Meyer and Lohse. Brautigam's superior, Georg Leibbrandt (interrogation of October 7, 1948, fol. 42R), referred to a meeting between Rosenberg and Lohse that was supposed to have occurred following a conversation between Rosenberg and Hitler. If they had been acquainted with the exact course of events, both of these men would surely have tried to mitigate their guilt at this crucial point in the proceedings by referring to the events of the Reichsleiter's and Gauleiter's meeting and by claiming that they had been obliged to act as they did because of a direct command from Hitler.

${ }^{136}$ In his letter to Rosenberg, February 5, 1942 (BA-MA FPF-01/7865, fol. 790), Lohse mentioned a "confidential address to the Reichsleiter and Gauleiter" that Hitler had delivered not long before. The details of his description agree with Goebbels's notes. For the general order to keep silence cf. Rebentisch (n. 87 above), p. 290.

${ }^{137}$ Otherwise additional discussions between the civilian authorities in the occupied territories and the Higher SS- and Police Leaders on the subject would have been pointless. The executions of the Jews in the Reich Commissariat Ostland were suspended for several months beginning December 1941. They were not resumed on a large scale in the Baltic until 1943. 
tant to remember in understanding Hitler's initiative of December 1941. His was not a concrete directive to begin immediately with an all-encompassing liquidation of the Jews. Rather, it was a decision in principle. The practical implementation, organization, and tempo of the extermination remained matters for the relevant local bodies to determine.

On December 16, at a meeting of the officials of the General Government, Hans Frank delivered an infamous address. In several of its passages he alluded unmistakably to Hitler's announcement of his decision on December 12:

As for the Jews, well, I can tell you quite frankly that one way or another we have to put an end to them. The Fuhrer once put it this way: if the combined forces of Judaism should again succeed in unleashing a world war, that would mean the end of the Jews in Europe. . . . I urge you: Stand together with me ... on this idea at least: Save your sympathy for the German people alone. Don't waste it on anyone else in the world,... . As a veteran National Socialist I also have to say this: if the Jews in Europe should survive this war, ... then the war would be only a partial success. As far as the Jews are concerned, I would therefore be guided by the basic expectation that they are going to disappear. They have to be gotten rid of. At present I am involved in discussions aimed at having them moved away to the east. In January there is going to be an important meeting in Berlin to discuss this question. I am going to send State Secretary Dr. Buhler to this meeting. It is scheduled to take place in the offices of the RSHA in the presence of Obergruppenfuhrer Heydrich. Whatever its outcome, a great Jewish emigration will commence.

But what is going to happen to these Jews? Do you imagine there will be settlement villages for them in the Ostland? In Berlin we were told: Why are you making all this trouble for us? There is nothing we can do with them here in the Ostland or in the Reich Commissariat. Liquidate them yourselves! . . . For us too the Jews are incredibly destructive eaters. . . . Here are 3.5 million Jews that we can't shoot, we can't poison. But there are some things we can do, and one way or another these measures will successfully lead to a liquidation. They are related to the measures under discussion with the Reich.... Where and how this will all take place will be a matter for offices that we will have to establish and operate here. I will report to you on their operation at the appropriate time. ${ }^{138}$

Frank was referring here to Hitler's speech of December 12, and above all to his words on "sympathy." His manner of expression clearly suggests, however, that he could not reveal precisely what had happened at the meeting of the Reichsleiter and Gauleiter. He went on to mention the discussions with the Ministry for the East and a centralized plan, still in its formative stages, for exterminating the Jews. Within the context of that plan, a liquidation organization would be created in the General Government. ${ }^{39}$ According to him, a

${ }^{138}$ Speech by Hans Frank, December 16, 1941, in Prag and Jacobmeyer, eds. (n. 119 above), pp. $457 \mathrm{ff}$.

${ }^{139}$ Frank had also conferred with Hitler at some point between December 10 and December 13. See Pohl, Lublin (n. 4 above), p. 103, n. 71. 
scheduled meeting with Heydrich would clarify the issues. That meeting was the Wannsee Conference.

On June 9, 1942, the day of a memorial service for Heydrich, who had been assassinated, Himmler delivered an infamous programmatic speech before an audience of high-ranking SS- and police officers. There he too employed a formula Hitler had used in his December 12, 1941, address: he announced a plan to exterminate all European Jews within a year, noting that "the table must be cleared." ${ }^{140}$ Hitler recalled his own words when he declared on February 14, 1942, that there was "no place for sentimental feelings" in connection with the destruction of the Jews. ${ }^{141}$ Upper SS leaders such as Himmler-intimate and SSGruppenfuhrer Gottlob Berger began to speak quite openly after December 1941 about killing all the Jews. ${ }^{142}$ Further, new guidelines on the subject may have been issued in the Wartheland on January 2, 1942. ${ }^{143}$

It is possible, hypothetically, that Hitler had already announced his decision before a smaller circle at some point between December 7 and December 12. ${ }^{144}$ Statements made by Eichmann after the war, however, make this seem relatively improbable. On several occasions Eichmann stated that Heydrich had called him in one day and told him that Hitler had ordered the extermination of the Jews. ${ }^{145}$ Two details of his account are significant. First, according to Eichmann, Heydrich had clearly gotten the information from Himmler. If a

${ }^{140}$ Speech to the SS-district leaders and Main Office heads, June 9, 1942, in Smith and
Peterson, eds., p. 159.
${ }^{141}$ Goebbels's record, cited by Broszat, p. 758. See also Goebbels, Tagebucher, pt. 2, vol. 2, pp. 533 ff. (December 18, 1941).

142 "Jews are second-class or third-order individuals. Whether or not one is justified in eliminating them is beyond debate. One way or another they must vanish from the face of the earth." Gottlob Berger to Oskar Dirlewanger, January 22, 1942, BA D-H ZM 1454, A.1, fols. $245 \mathrm{f}$.

${ }^{143}$ Artur Eisenbach, "Operation Reinhard: Mass Extermination of the Jewish Population in Poland," Polish Western Affairs 3 (1962): 80-124, esp. p. 83. Eisenbach mentions an enactment by Greiser, dated January 2, 1942, "regarding liquidation of the Jews (Entjudung) in the Wartheland." The enactment is mentioned in another document, but a record of it does not appear to have been preserved.

${ }^{144}$ On December 9, 1941, Hitler had a lengthy conversation with Goring (see n. 120). On the evening of December 7, and probably on December 10, he met with Himmler. Himmler himself met with Heydrich on December 9 and on December 11 (Himmler, appointment calendar, December 7-11, 1941, fols. 344-47).

${ }^{145}$ During his interrogation (May 31, 1960, in Trial of Adolf Eichmann [n. 25 above], p. 169), Eichmann maintained that this had occurred two months after the June 1941 invasion of the Soviet Union. In a handwritten correction he later added, "It might also have been three months afterwards." But abstract dates and temporal sequences of events related by Eichmann must be treated with caution and verified through other sources: his accounts are notoriously inconsistent and cannot in themselves be used to prove or disprove any thesis. Eichmann's statements can, however, be evaluated in the context of other evidence to determine which of these are most likely to be correct. 
meeting had been held between December 7 and December 11 to allow Hitler to announce his decision to exterminate all European Jews before a smaller circle of advisers, it is difficult to imagine that Heydrich would not have been present and would have had to learn about the decision from Himmler instead. After all, Heydrich was in town until December 11, so he was available to attend such a meeting, and it was Heydrich who had been given the commission to prepare the "total European solution of the Jewish question." 146

Second, Eichmann stated that he was sent immediately after his conversation with Heydrich to meet with Globocnik at the concentration camp in Belzec. ${ }^{147}$ Eichmann's descriptions of the status of construction at Belzec make it clear that his visit could not have occurred before December 1941. ${ }^{148}$ Most experts have declared this to be impossible since, according to their theories, such a date would be "too late." ${ }^{149}$ Eichmann's more general recollection of being sent to Belzec immediately after an important decision had been announced would, however, be consistent with Hitler's having made his decision in December 1941.

Hitler announced his decision to liquidate European Jewry to the party leadership on December 12. ${ }^{150}$ Just five days later the leaders of the seven regional evangelical churches announced the exclusion from the church of all individuals bearing the Jewish star. They demanded that Jews be deported from Germany as "born enemies of the Reich and of the world," employing a formulation similar to Hitler's. Finally, they demanded that "the most severe measures" be taken against the Jews. Logically this could mean only one thing: their destruction. ${ }^{151}$ Such a proclamation, offensive as it is by itself, seems even more

${ }^{146}$ This is another reason making it less likely that Hitler could have issued his order in the Reichstag, perhaps in a closed session following the official meeting on December 11, 1941, for Heydrich was a member of the Reichstag. Rosenberg's assertion during his interrogation on April 17, 1946 (IMT, vol. 11, pp. 607 f.), could be interpreted to mean that Hitler did issue such a statement as part of his.December 11, 1941, Reichstag address. But Rosenberg.'s assertion is ambiguous. For Goring's commission to Heydrich of July 31, 1941, see Patzold and Schwarz, eds., p. 79.

${ }^{147}$ Ibid. For Himmler's information to Heydrich, see Rudolf Aschenauer, ed., Ich, Adolf Eichmann: Ein historischer Zeugenbericht (Leoni, 1980), pp. 177 ff. On another occasion, in his interrogation of July 5, 1960, Eichmann asserted that the visit to Globocnik occurred some two months after the Wannsee Conference (Trial of Adolf Eichmann, vol. 17, fol. 56 [p. 845]).

${ }^{148}$ So, too, in Safrian (n. 5 above), p. 171.

${ }^{149}$ Hilberg, Vernichtung (n. 17 above), p. 421; Burrin (n. 5 above), pp. 146 ff., maintains that Eichmann is confusing two different things.

${ }^{150}$ In a handwritten statement on June 22, 1945, Dr. Rudolf Mildner, the last commander of the Security Police in Vienna, also drew a connection between the United States's entry into the war and the execution of Hitler's threat that the Jews in Europe would "be exterminated for it" (Nuremberg Document PS-2376).

${ }^{151}$ Cited in Daniel Jonah Goldhagen, Hitlers willige Vollstrecker (Berlin, 1996), pp. $142 \mathrm{ff}$., with whose conclusions I concur at this point. For an earlier reference see Raul 
incriminating in view of its proximity to the meeting of party officials and regional leaders. Church leaders were usually well-informed politically. Further research will be needed to show whether some connection actually existed.

\section{The Wannsee Conference and Its New Context: CONTENTS AND RESUlTS}

On December 8, 1941, one day before it was originally scheduled to take place, the Wannsee Conference was postponed indefinitely. ${ }^{152}$ Various explanations for the postponement have been proposed. In the second set of invitations, sent out on January 8, 1942, Heydrich wrote that he had to cancel the original meeting "because of events that were announced suddenly, requiring the attention of some of the invited participants." 153 Some historians believe that Heydrich was referring to the Japanese attack on Pearl Harbor on December 7. Others believe he meant the Soviet counteroffensive in the Battle of Moscow, which began on December $5 .{ }^{154} \mathrm{At}$ the originally scheduled time for the conference, at noon on December 9, there was something "requiring the attention" of Heydrich himself: he had to present a report to Himmler. ${ }^{155}$ According to the account cited earlier by Labs, the meeting had to be postponed "because of the session of the Reichstag." ${ }^{156}$ That is a possibility. The session did not actually take place until December 11, but it had been postponed more than once. Why the conference had to be postponed for six weeks is unclear. Perhaps Hitler's speech on December 12 had so altered the context for the meeting that new preparation was needed. ${ }^{157}$ Hitler's fundamental decision had, as a matter of fact, created a new and rather horrible "framework for planning" for the RSHA. Perhaps Heydrich's meeting with Goring on January 12, 1942, furnished another opportunity to discuss the new situation in antisemitic policy. ${ }^{158}$

Hilberg, Tater, Opfer, Zuschauer: Die Vernichtung der Juden, 1933-1945 (Frankfurt am Main, 1992), p. 285.

${ }^{152}$ Tuchel (n. 3 above), p. 114.

${ }^{153}$ Heydrich to Undersecretary of State Martin Luther, January 8, 1942, facsimile reproduction in Tuchel, p. 115.

${ }^{154}$ See Safrian, p. 169.

${ }^{155}$ Himmler, appointment calendar, December 9, 1941, 12:40 P.M., fol. 346.

${ }^{156}$ For documentation, see n. 96.

${ }^{157}$ One should also recall in this connection the meeting between Himmler and Buhler on January 13, which had been arranged on January 2, 1942 (for documentation, see n. 69). Jackel (n. 1 above), p. 33, suspects that Heydrich was in no hurry because the meeting was to deal primarily with the issues of representation and the establishment of his authority.

${ }^{158}$ The.contents of the conversation are unknown. The original purpose of Heydrich's visit to Goring had simply been to convey his birthday greetings. But Heydrich "remained 
We have already reviewed the participants at the conference. Present were five representatives from the Security Police and the SD, eight politicians and functionaries from the civil administration, and two representatives from the party, one from the party chancellery and one from the Race and Resettlement Office of the SS. Some of those invited sent representatives. Two were absent: Leopold Gutterer, the state secretary from the propaganda ministry, and Ulrich Greifelt, the director of the Staff Office of the Reich Commissar for the Strengthening of Germandom. (Greifelt may have been at a conference in Italy.) ${ }^{159}$ Since policy issues rather than technical matters were under discussion, representatives from the Reich finance ministry and from the Reich transportation ministry had not been invited. ${ }^{160}$ Of all the offices affected by the problem of how to define "Jewish," only the Fuhrer Chancellery and the Armed Forces High Command were not present. ${ }^{161}$

Heydrich opened the meeting with a long presentation. He reviewed Goring's commission to "prepare a Final Solution for the Jewish Question in Europe." He emphasized that overall responsibility and authority were his. He expressed his desire that all their efforts should proceed, after appropriate consultation, in parallel. Finally, he summarized the progress of antisemitic policies, emphasizing developments since 1939: the stage of forced individual emigration and, "with appropriate prior approval by the Fuhrer," the stage of collective "evacuation of the Jews to the east." 162

He then went on to outline his plan for a "Final Solution," involving the mass murder of Jews from all the countries of Europe, including allied, neutral, and hostile nations. Some of the Jews would first be employed for forced labor. ${ }^{163}$ A brief discussion involving Heydrich, Martin Luther (from the Reich foreign ministry), and Otto Hofmann (from the SS Race and Resettlement Office) touched on potential difficulties and possible diplomatic initiatives that could be involved in implementing the plan in occupied and allied countries.

with the Reich Marshall for official purposes," and Heydrich's next appointment had to be postponed for an hour. See note by Franz Bentevegni (Armed Forces High Command, Office for Foreign Defense), January 13, 1942 (unsigned), BA-MA RW 5/v.690, fol. 21. The incident is also mentioned in Heydrich to Canaris, February 5, 1942, BA NS 19/ 3514, fols. 141-45.

${ }^{159}$ Aly (n. 5 above), p. 364, where the general role in Jewish policy played by the Reich Commission for the Strengthening of the German Folk is also discussed. For more information about the participants, see Sec. II.

${ }^{160}$ Scheffler (n. 2 above), p. 25.

${ }^{161}$ For more information about the role of the Armed Forces High Command, see Bryan Mark Rigg, "Judische Mischlinge in der Wehrmacht" (in press). On the issue generally, see Noakes, pp. 328-36.

${ }^{162}$ Undated minutes, fols. 2-5 (Tuchel, pp. 123-26).

${ }^{163}$ Minutes, fols. 5-8 (Tuchel, pp. 126-29). 
Few problems were foreseen, though Heydrich did note that the deportations would be dependent on military developments on the eastern front. ${ }^{164}$

Next, Heydrich presented his ideas for expanding the definition of "Jewish." Basically his ideas reflected the proposals that had been agreed to several months earlier by a commission drawn from RSHA, party chancellery, and Four-Year Plan officials. ${ }^{165}$ "Part-Jews of the first degree" were to be treated, with few exceptions, "like Jews." Further, the same treatment was to be meted out to some "part-Jews of the second degree" and to Jews married to nonJewish spouses. ${ }^{166}$ Hofmann objected, proposing voluntary sterilization as an alternative to deportation. Wilhelm Stuckart objected as well, though he favored involuntary sterilizations of "part-Jews of the first degree." Stuckart also suggested passage of a law requiring the dissolution of such "mixed marriages," to be followed by the deportation and execution of the Jewish spouse. But he made no use of the arguments prepared by his subordinate, Losener, to object to further measures against these two groups. ${ }^{167}$

Finally, State Secretary Josef Buhler (from the General Government) acknowledged the authority of the Security Police and the SD for conducting anti-Jewish activities. Buhler and Alfred Meyer, the representative from the Ministry for the East, pressed for a beginning of the "Final Solution" in their territories. ${ }^{168}$ It should be noted that Meyer, the Gauleiter for North Westphalia, was the only participant at the Wannsee Conference who had also been present at Hitler's address to the Reichsleiter and Gauleiter on December 12, 1941.

Heydrich was quite pleased with the results of the conference. ${ }^{169}$ One may well wonder why. He had expected opposition from Buhler and especially from Stuckart. ${ }^{170}$ Buhler, after the discussions preceding the conference, had raised no objections - quite the contrary! But Stuckart had been ready to compromise only on the issue of mixed marriages. As for the issue of the "part-

${ }^{164}$ Minutes, fols. 9 f. (Tuchel, pp. 130 f.).

${ }^{165}$ Notation by Losener for Stuckart, December 4, 1941, enclosure 1, BA R 18/5519, fols. $483-85$.

${ }^{166}$ Minutes, fols. 8 f., 10-13 (Tuchel [n. 3 above], pp. 130 f., 132-34).

${ }^{167}$ Minutes, B1 13 f. (Tuchel, pp. 134 f.). On this point the accuracy of the minutes is confirmed by Stuckart's letter to some of the conference participants, March 16, 1942, in Patzold and Schwarz, eds., pp. 121 f. Losener's Notation for Stuckart, December 4, 1941, BA R 18/5519, fols. 477, 483-95.

${ }^{168}$ Minutes, fols. 14 f. (Tuchel, p. 135 f.).

${ }^{169}$ In this regard, at least, Eichmann's postwar testimony (e.g., interrogation, June 26, 1961, in Trial of Adolf Eichmann, vol. 4 [Jerusalem, 1993], p. 1423) is confirmed by Heydrich's cover letter accompanying the minutes, February 26, 1942 (reproduced in facsimile in Tuchel, p. 121).

${ }^{170}$ Eichmann Document, March 7, 1961, in Patzold and Schwarz, eds., p. 184; interrogations of Eichmann, June 26 and July 17, 1961, in Trial of Adolf Eichmann, vol. 4, pp. $1423,1711 \mathrm{ff}$. 
Jews," no agreement had been possible, nor was one ever reached later. ${ }^{171}$ On January 29, the party chancellery released a report that this issue was still undecided. Indeed the adviser on racial affairs in the Ministry for the East, relying on Bernhard Losener, noted that the party chancellery was now opposed to the harsher treatment of "part-Jews." ${ }^{172}$ One certainly cannot say that the issue was decided in Heydrich's favor at the Wannsee Conference. ${ }^{173}$ On the contrary, on the one apparently undecided subject Heydrich's proposal had failed.

Nonetheless, Heydrich's ultimate authority had been recognized, explicitly so by Buhler, implicitly by the others. That should hardly be surprising. If the term "Final Solution" was now to be equated with "murder," who would have been in a position to dispute his responsibility? Who would have wanted to? In fact, some officials were quite pleased to be able to act as if they could wash their hands of the matter. One adviser from the Ministry for the East, present at a follow-up meeting to the Wannsee Conference, was struck by the fact that the meeting chairman, the section leader Dr. Otto Brautigam, from his own office, appeared so eager to submit and to make concessions to the SS. When asked why, Brautigam said, "that as far as the Jewish question was concerned he was quite happy to emphasize the responsibility of the SS and the police." ${ }^{174}$ His statement is all the more worthy of note in that Brautigam had already stated publicly, at the time, that Germany could no longer achieve a military victory in the war. ${ }^{175}$ Apparently his thoughts had already begun to turn toward his own personal future. ${ }^{176}$

${ }^{171}$ Wilhelm Stuckart's role is a matter of dispute. A definitive answer does not seem to me to be possible. He later contended that he made his proposal to substitute compulsory sterilization for deportation knowing that the former was technically impossible to implement, and his assertion is difficult to dispute. Furthermore, with regard to the issue of compulsory divorce, he proposed a legal measure that could be delayed in a great variety of ways, and this is just what did happen later.

172 "The future treatment of this class of individuals [the so-called part-Jews of the first degree] remains undecided," memo of the Party Chancellery, January 29, 1942, cited in a circular letter from the Main Office for National Prosperity (Hauptamt fur Volkswohlfahrt), April 13, 1942, in Herwart Vorlander, Die NSV (Boppard, 1988), p. 427; Aly and Heim (n. 5 above), p. 470; see also their source document, undated note by Dr. Wetzel, BA R $6 / 74$, fol. 79 .

${ }^{173}$ Adler (n. 46 above), p. 304. On this issue, see also record of Franz Rademacher, March 7, and note from the Reich Foreign Ministry D III, June 11, 1942, in Klein (n. 3 above), pp. 57-60.

${ }^{174}$ Note by Lindemann (Main Office II, Administration, Ministry of the East), February 11,1942 , BA R 6/74, fol. 78 .

${ }^{175}$ See Himmler's indignant notation in his meeting notes from his meeting with Hitler,. Rosenberg, Lammers, and Wilhelm Keitel on February 15, 1942: "Remark by Brautigam: [']The war in the east can no longer be won militarily,[']" BA NS 19/1448, fol. 12 .

${ }^{176}$ As a matter of fact.Brautigam was to.escape punishment after the war. In the opinion of the Landgericht of Nurnberg-Furth, Brautigam's personal responsibility for the murder of Soviet Jews had not been proven. See the Proceedings Staatsanwaltschaft Nurnberg- 
In my opinion, Heydrich's satisfaction with the outcome of the Wannsee Conference arose for another reason. No one had voiced opposition to the extermination of the Jews, including those in the German Reich and in western Europe. ${ }^{177}$ In official terminology: no reservations were expressed. The minutes support this conclusion indirectly. They record no objections, though differences and disagreements on other topics are noted. It certainly would have been conceivable for governmental or administrative officials to voice reservations, practical or political if not moral ones, in the face of Hitler's decision on December $12 .{ }^{178}$ They did not do so. Luther and Buhler voiced agreement, Kritzinger and Freisler remained silent, and Stuckart confined his objections to the issue of "part-Jews." It was not without some reason, therefore, that Heydrich could write, on February 26, that Wannsee, "happily, has settled the basic outlines for the practical implementation of the final solution of the Jewish question." He admitted that not all the details had yet been settled. ${ }^{179}$ For Heydrich, January 20, 1942, was a day to celebrate, a day when he had also signed a list of nominees for the War Service Cross Second Class. At the top of the list was Paul Blobel, up until now the head of the Sonderkommando 4a and the man responsible for the slaughter of Jews at Babi Yar. Third on the list was Dr. Albert Widmann, who had carried out extermination experiments using poison gas in Mogilev in White Russia. Also on the list were Widmann's assistant, Schmidt, three other RSHA officials from Referat II D 3 a, the office responsible for the development of the gassing vans, and various members of the Einsatzkommandos. ${ }^{180}$

Yet the plan Heydrich presented on January 20, 1942, was not completely clear. Heydrich died on June 4, 1942, and it is very likely that he never succeeded in presenting to Goring a "Complete Proposal" for the "Final Solution of the Jewish Question," as his commission of July 31, 1941, had put it. ${ }^{181}$ Just

Furth 72 Ks 3/50a-b in the Staatsarchiv Nurnberg. In 1955 Brautigam became director of the Section for Eastern Affairs (Ostabteilung) in the foreign ministry of the Federal Republic. Public pressure later forced him to retire.

${ }^{177}$ In itself that is nothing new. See, e.g., Wolfgang Scheffler, Judenverfolgung im Dritten Reich (West Berlin, 1964), p. 38; Ludolf Herbst, Das nationalsozialistische Deutschland, 1933-1945 (Frankfurt am Main, 1996), p. 387. It must be stressed, however, that this was the most important outcome of the meeting.

${ }^{178}$ As a parallel, one might point out Hitler's repeated prohibition against using the inhabitants of the occupied Soviet territories as armed collaborators (e.g., document note by Bormann on the Leadership Conference, July 16, 1941, IMT, vol. 38, p. 88). This was a significant ideological issue in terms of the creation of a German empire in the east. Hitler never succeeded in compelling either the armed forces or the SS to observe his prohibition.

${ }^{179}$ Quoted from the facsimile reproduction in Tuchel, p. 121; emphasis added.

${ }^{180}$ BA D-H ZR 759, A. 14.

${ }^{181}$ Goring's commission of July 31, 1941, is in Patzold and Schwarz, eds. (n. 23 above), p. 79. The.minutes of the Wannsee Conference were not the desired "comprehensive plan" as Patzold and Schwarz assert (p. 47). This is clear from the fact that on February 
five days before Heydrich's assassination, Lammers had sent him a letter from the Reich interior minister concerning the issue of "part-Jews of the first degree" in order for Heydrich "to review it for your report to Reich Marshall Goring." 182 Presumably Heydrich had been hoping for Hitler's fundamental decision for some time. When it was announced on December 12, 1941, however, Heydrich had no ready-made plan for extermination that he could simply pull off the shelf. And if Heydrich did not have a complete plan in December 1941 indicating how the murder of all European Jews was supposed to be carried out, the conclusion has to be that such a plan could not have existed before the beginning of 1942. What Heydrich proposed at the Wannsee Conference had a provisional, in some places utopian, character. This much is reflected in the central passages of the minutes about the future treatment of the Jews:

In the course of the final solution, the Jews should be brought in an appropriate manner and under appropriate direction to work in the east. In large detachments, with the sexes separated, the Jews who are able to work will construct roads in these regions. It is to be expected that a sizable number will disappear due to natural causes.

The Jews who survive, however many there may be, will no doubt be the hardiest. They will have to be treated accordingly. Otherwise these select few, should they escape, could form the basis for a new Jewish line of descent. (See the experience of history.)

Gerald Reitlinger has observed that "unless the words of the German language had lost their meaning," what Heydrich meant was execution. ${ }^{183}$ And if that

26 Heydrich sent out invitations for a follow-up conference to be held on March 6 "in order to prepare the necessary document for the Reich Marshall" (facsimile reproduction in Tuchel, p. 121). Hence the "comprehensive plan" could not have been completed in February, and it cannot be identical with the RSHA discussion document that Goebbels read on March 7 (for the opposite view, see Aly and Heim, p. 460). Similarly, the suggestion that Goring appointed Heydrich "Commissar for Jewish Affairs in Europe" (Aly and Heim, p. 460) appears to be not correct (see Scheffler, "Wannsee-Konferenz," p. 33, n. 9).

${ }^{182}$ Lammers.to Heydrich, May 22, 1942 (copy), BA R 18/5519, fol. 481. A report by Heydrich to Goring was planned but probably never delivered because Goring was able to discuss the issues important to him with Himmler on July 2, 1942. See document from Ministerial Counsellor Dr. Ing. Fritz Gornnert (Goring's personal adviser) "with request for documents for scheduled meeting with Obergruppenfuhrer Heydrich,” May 24, 1942, and documents from Gornnert, July 1, 1942, for the meeting with Himmler, BA 34.01 FC Nr. 376, fols. 7569, 7984 f., 7897; Himmler, appointment calendar, July 2, 1942, fol. 182. Strictly speaking, Heydrich could not possibly have presented a "comprehensive plan" to Goring because he had not yet obtained approval from all relevant offices. Because of a clerical error, the RSHA had neglected to send a copy of the minutes from the follow-up meeting held on March 6, 1942, to the foreign office. It only did so on July 3, 1942, some time after Heydrich's death. The reply from the foreign office is dated October 2, 1942. See RSHA IV B 4 (Friedrich Suhr) to the Foreign Office (Franz Rademacher), July 3, 1942, and the reminder, August 12; and Foreign Office D III 67 gRs to RSHA, October 2 and December 7, 1942, BA F 10531.

${ }^{183}$ Reitlinger (n. 17 above), p. 108. See also Patzold and Schwarz, eds., p. 51; interrogation of Adolf Eichmann, July 5, 1960, in Trial of Adolf Eichmann, vol. 7, Band 17, fols. 56 
was true for the surviving Jews who were capable of working, it must have been truer still for those unable to work, especially for the women and children. Buhler pointed this out explicitly. Despite the deliberate use of misleading terms, it is clear that large programs of forced labor continued to play a significant role in the RSHA's plans. Road construction in the Soviet Union was one project. Another involved vaguely discernible plans for labor and penal colonies in northern Russia, near the Arctic Ocean. ${ }^{184}$ Not much was to come of these plans. In a meeting with Himmler on February 17, 1942, Hitler himself rejected the Arctic Ocean schemes, which he had learned about from a memorandum that presumably had been worked out by the RSHA. He reaffirmed his position in early April, noting that he had a more pressing need for this labor power in the German war economy. ${ }^{185}$

Two other parts of Heydrich's plan differed from what was later to take shape. In Heydrich's scheme, Europe was to be "combed from west to east." Jews were to be deported first from the Reich, then from the Protectorate of Bohemia and Moravia, then from western Europe, and finally from eastern Europe. Hitler expressed similar ideas in May 1942. ${ }^{186}$ But this approach conflicted with the plan of the foreign office, according to which the deportations were to begin in southeast Europe. ${ }^{187}$ A considerable difference of opinion on this issue surfaced at the Wannsee Conference. As a matter of fact, the systematic and complete extermination of the Jews began in the occupied territories of the Soviet Union and in the General Government, just as Buhler and Meyer had insisted. Buhler had argued that a majority of Jews in the General Govern-

ff. (p. 845 ff.). Eichmann admitted that the "possible solutions" mentioned in the minutes meant methods of execution. Interrogation, July 21, 1961, in Trial.of Adolf Eichmann, vol. 4, p. 1810. The "certain preparatory measures" mentioned by Buhler and Alfred Meyer, which were "to be implemented in the relevant territories themselves, in a manner that would not create unrest among the inhabitants" (minutes, fol.15, in Tuchel, p. 136) were nothing more, in my opinion, than code words for "mass shootings."

${ }^{184}$ See Hermann Kaienburg, "Judische.Arbeitslager an der 'Strasse der SS, " 1999 , no. 1 (1996): 13-39, esp. pp. 13 f.; Sandkuhler (n. 4 above), pp. 137 ff. Heydrich is said to have mentioned an "Arctic Ocean camp" in preliminary discussions with Buhler, interrogation of Josef Buhler, April 23, 1946, in Patzold and Schwarz, eds., p. 135. On the subject generally, see Karl Heinz Roth, “'Generalplan Ost'-'Gesamtplan Ost.' Forschungsstand, Quellenprobleme, neue Ergebnisse," in Der “Generalplan Ost,” ed. Mechtild Rossler and Sabine Schleiermacher (Berlin, 1993), pp. 25-117, esp. pp. 40 ff., 62 f.; Burrin, p. 151 (conversation between Heydrich and Goebbels, September 25, 1941); speech by Heydrich, February 4, 1942, in Karny et al., eds., p. 229; Himmler to Heydrich and to Wilhelm Rediess, the Higher SS- and Police Leader in Norway, February 16, 1942, BA NS 19/2375, fols. $1 \mathrm{f}$.

${ }^{185}$ See Himmler, report notes, February 17, 1942, BA NS 19/1447, fols. 55 f.; Henry Picker, Hitlers Tischgesprache im Fuhrerhauptquartier, 3d ed. (Stuttgart, 1977), p. 192.

${ }^{186}$ Minutes, fol. 8 (Tuchel, p. 129); Goebbels, Tagebucher, pp. 533 f. (December 18, 1941); Hitler, May 29, 1942, in Picker, p. 340.

${ }^{187}$ On this subject, see Browning, Final Solution (n. 75 above), p. 79. 
ment were not capable of work, endangered the economy through their blackmarket activities, and ought to disappear. ${ }^{188}$ As noted earlier, Hans Frank had already characterized the Jews in his liquidation speech on December 16, 1941, as "extraordinarily destructive eaters." 189

Finally, the schedule underlying the discussions in Wannsee seems not to agree with the later tempo of extermination. The huge forced labor projects were not realized. The destruction of the Jews was accelerated in April of 1942, and then again during the summer of that year. This much is indicated by the pace of construction at the extermination camps. It is also confirmed in later statements made by one of the conference participants, Otto Hofmann. In late September 1942 he revealed his ideas on future generations to a meeting of SS Officers, noting that "They will no longer recognize any Jewish danger. In twenty years there may not be a single Jew left. In the European part of Russia there are a total of some 11 million Jews [!]. So there is still plenty of work to do. I cannot believe that we have exterminated more than one million of them thus far. It will take some time until we have freed Europe from this pestilence." 190

Hofmann was clearly referring to his recollection, even then somewhat dim, of the Wannsee Conference. The pace of liquidation had actually been faster than he thought. For he had not been kept informed about current developments and had just met with Himmler for the first time since February 1942. ${ }^{191}$

\section{The Results of the Wannsee Conference}

News about the outcome of the meeting in Wannsee spread quickly. Heydrich gave Himmler a telephone report on the following day. Alfred Meyer reported to Rosenberg. Globocnik traveled to Berlin, probably on January 23. Hitler, too, seems to have been informed without delay. ${ }^{192}$ It is possible that reports

${ }^{188}$ Minutes, fols. 14 f. (Tuchel, pp. 135 f.).

${ }^{189}$ Prag and Jacobmeyer, eds., p. 459.

${ }^{190}$ See final comments by SS-Gruppenfuhrer and General Lieutenant of the WaffenSS, Hofmann, at a Conference of SS-Leaders from the Race and Resettlement Office, September 29-30, 1942, BA 17.03, Nr. 2, fol. 58; emphasis added. At the Wannsee Conference it had been asserted that in Europe there were 11 million Jews, in the European part of the Soviet Union 5 million. The mistake may have been made by the individual who prepared the minutes of the speech.

${ }^{191}$ See Himmler, appointment calendar; Grothmann, appointment calendar.

${ }^{192}$ Himmler, notes on telephone conversations, January 21, 1942 ("Jewish question. Meeting in Berlin"), BA NS 19/1439; Rosenberg, appointment calendar, January 21, 1942, BA NS 8/133, fol. 8; Globocnik report in Dirlewanger to Friedrich (SS Main Office), January 22, 1942, BA D-H ZM 1454, A.1, fol. 231; Hitler's antisemitic outbursts in the presence of Himmler and Lammers on January 25, 1942 are documented in Jochmann, ed., pp. $228 \mathrm{f}$; on the flow of information in the foreign office, see Browning, Final Solution, pp. $76 \mathrm{ff}$. 
reached Slovakia as early as the end of January. ${ }^{193}$ By July 1942 German officials in the General Commissariat in Latvia were fully informed. ${ }^{194}$

On the issue of "part-Jews" and "mixed marriages" the discussions soon deadlocked. The new deportation directives issued by Eichmann on January 31, 1942, continued to follow the Nuremberg Laws. Jews married to non-Jews, Jewish foreigners, Jewish workers in armaments plants and in agriculture, and the elderly continued to be exempted. ${ }^{195}$ On March 6 the first official followup conference at the expert level was held. The suggestions Stuckart had made at Wannsee were examined. Sterilization was rejected as an organizational impossibility, but more detailed plans for compulsory legal divorce were formulated. ${ }^{196}$ On March 16 Stuckart continued to insist that the class of individuals labeled as part-Jews of the first degree should not receive harsher treatment than before. At this point he adopted the arguments that had been drafted for his use at the Wannsee meeting by Losener. The acting Reich justice minister, Franz Schlegelberger, wrote two letters in support of Stuckart's position. Subsequently, on April 10, Lammers met with Schlegelberger to discuss the "Complete Solution of the Jewish Question." ${ }^{197}$ By September 1942 Stuckart seems to have succeeded in convincing Himmler. Consequently, the second follow-

${ }^{193}$ An official in the Slovakian Office for Jewish Affairs is said to have remarked in late January of 1942 that Slovakian Jews would soon be deported and executed...See Walter Lacquer, Was niemand wissen wollte: Die Unterdruckung von Nachrichten uber Hitlers Endlosung (Frankfurt am Main, 1981), pp. 175 ff.

${ }^{194}$ General Commissar for Latvia, IIa-Sch/Hue to the Reich Commissar for the Ostland, July 11, 1942: "In the Reich, the direction of current efforts is not to equate partJews of the first degree with Jews; the former are to be sterilized (see the meeting of the state secretaries on January 20, 1942)" (Lettisches Staatsarchiv Riga 69-1a-6, fol. 53). I am indebted to Christoph Dieckmann for calling my attention to this document.

..${ }^{195}$ RSHA IV B 4, express letter, in re: Evacuation of the Jews, January 31, 1942, in Kurt Patzold and Erika Schwarz, "Auschwitzwar fur mich nur ein Bahnhof": Franz Novak, der Transportoffizier Adolf Eichmanns (Berlin, 1994), pp. 119-22.

${ }^{196}$ Undated and unsigned report, reproduced in facsimile in Mendelsohn, ed. (n. 20 above), pp. 86-94; undated report by Franz Rademacher, in Mendelsohn, ed., pp. 208 f.

${ }^{197}$ For these two prominent participants in the Wannsee meeting, see Wilhelm Stuckart, March 16, and Franz Schlegelberger, April 5, 1942, in Mendelsohn, ed., pp. 201-7; Schlegelberger to Lammers, March 12, 1942, Nuremberg Document NG-839; Noakes, pp. 345 f.; Adam, pp. 324 ff.; Hilberg, Vernichtung, pp. 441 f. In addition, see note by Losener, December 4, 1941, Anlage 2, BA R 18/5519, fols. 487-95; meeting notes of Lammers, April 10, 1942 (the actual record is missing), BA R 43 II/4023, fol. $2 /$ R. Stuckart and Schlegelberger referred directly to points in the minutes of the Wannsee Conference. So they were familiar with this document, as was Martin Bormann (see n. 214). Distribution of the minutes was announced on January 21, at the latest; see Rademacher's note, dated January 21, on Heydrich's invitation to the foreign office of January 8,1942 , "Minutes of the meeting are announced to arrive later" (reproduced in facsimile in Tuchel, p. 115). Hence suspicions that have been expressed (see Klein [n. 3 above], pp. $16 \mathrm{f}$.) that the distribution of the minutes was narrowly limited are unfounded. 
up meeting to the Wannsee Conference, held on October 27, produced no new results. ${ }^{198}$ At about this same time the new Reich justice minister, Otto Thierack, and Goebbels expressed their opinion that "the issue of part-Jews should not be resolved during the war." Even the notorious RSHA chief of Section III B (Foreign Nationalities), Hans Ehlich, declared that the "lineage investigations" of the Reich Genealogy Office were dispensable "because in the course of nine years the percentage of cases discovered involving foreign blood was relatively small" and could be ignored. ${ }^{199}$ Further, despite an apparent breakthrough in March 1943 when Reich Interior Minister Wilhelm Frick obtained Hitler's approval, the plans developed by various offices for compulsory legal divorces in cases of "mixed marriages" came to nothing. ${ }^{200}$ The majority of "half Jews," "quarter Jews," and Jewish partners in "mixed marriages" were thus able to survive the war despite these repeated efforts at persecution.

In the immediate aftermath of the Wannsee Conference, however, the RSHA believed that the time was ripe to hunt down "part-Jews" throughout Europe and to execute them. In early February 1942, the adviser on Jewish affairs in the SD office in Paris, Theodor Dannecker, urgently requested that a genealogical researcher be hired to begin an immediate examination of the lineages of "Jews and part-Jews." ${ }^{201}$ It was an opinion from Mayer, the chief of the Reich Genealogy Office, in March that first put a damper on the enthusiasm. He concluded that there simply were not enough documents available to carry out an investigation for Jewish ancestors in the family lineages of some seventy thousand cases. The project was canceled. ${ }^{202}$ In the Netherlands, too, where the SS

${ }^{198}$ Stuckart to Himmler, September 1942, in Losener, "Rassereferent," pp. 298-301; Adam, pp. 327 f., but see also p. 329, n. 132; Grenville (n. 54 above), pp. 111 f.

${ }^{199}$ Note by Otto Thierack, October 26, 1942, BA R 22/4062, fols. 14 f.; Note, in re: Reich Genealogy Office by Hans Ehlich, January 25, 1943, BA RW 42/4, Heft 2. (There were some 24,000 "cases" requiring 140,000 investigations.)

${ }^{200}$ See Hilberg, Vernichtung, pp. 446-49; Adler, p. 299; Adam, p. 329; Noakes, p. 348; for the course of events, see BA R 22/460, particularly Wilhelm Frick to Otto Thierack, March 20, 1943, fol. 334; BA R 18/5519, fols. 509 ff.

${ }^{201}$ SS Race and Resettlement Main Office, Ancestry Section, to Kurt Steudtner, February 12,1942 . See the additional correspondence between the same parties in February and March, 1942, and the reaction of the applicant, Kurt Steudtner, in a letter to Otto Hofmann, March 2, 1942: "In the midst of my antiquarian historical researches came your job offer, holding out the promise of new struggles in the country beyond the Rhine. . . The realization of this project is still subject of official discussion. . . I I can assure you that from the very first moment of my arrival at the Paris battle station, I will be ready to apply all my powers and abilities without rest in the struggle against the world's number one enemy!" BA NS 2/1002. In addition, see report by Theodor Dannecker, February 22, 1942, in Patzold, ed., pp. 343-45.

${ }^{202}$ Teletype by Dannecker to Wilhelm Osiander, March 21, and letter, March 31, 1942, BA NS 2/1002; note, in re: Mechanisms for Identifying Concealed Jewish Identities in 
had compiled a national "registry of Jews and part-Jews," a systematic deportation of part-Jews seems never to have been undertaken. ${ }^{203}$

For the German Jews in Riga and Minsk, however, the results of the Wannsee Conference were soon to prove calamitous. In early February 1942, in Riga, selections began to be made openly: Jews deemed "incapable of work" were shot by the Security Police or murdered in gassing vans. ${ }^{204}$ After being informed in Riga of the outcome of the Wannsee Conference, the Commander of the Security Police and of the SD (KdS) in Minsk, Walter Hofmann, announced on January 29, 1942, that he wanted to initiate a "vigorous schedule of executions" in the spring. Hofmann cynically remarked that one had to cultivate the belief prevailing among the deported German Jews that they would be allowed to return to their homes after the war in order to get them to work harder. On February 6, General Commissar Wilhelm Kube indicated that he would order the executions of Jewish deportees arriving on subsequent transports from the Reich because there was not enough food or shelter for them. ${ }^{205}$ Members of the German Jewish Council were arrested by the Security Police in early February. One month later they were executed. According to one witness, on March 31, German Jews in the Minsk ghetto were executed for the first time in the course of a "small" massacre. ${ }^{206}$

The new wave of deportations to the east from within the German Reich and from central and western Europe began slowly. The crisis in rail transport in the occupied Soviet territories had had significant effects on the situation in the Reich. On January 26, Albert Speer informed Rosenberg that additional Jewish transports would have to be postponed until April. Even the deporta-

France, March 24, 1942, BA R 39/762; see notes, November 8 and November 11, 1941 (BA R 39/762).

${ }^{203}$ Hanns-Albin Rauter (Higher SS- and Police Leader, Northwest) to Otto Hofmann, December 20, 1941, BA NS 2/83, fol. 81/R; SS-Leader in the Race and Resettlement Office to Rauter, July 14, 1942, BA NS 2/81, fol. 122.

${ }^{204}$ Safrian, pp. 180 f.; Press, p. 120; Ezergailis, p. 359.

${ }^{205}$ Interrogation of Georg Heuser, February 14, 1966, Staatsanwaltschaft Hamburg 147 Js 29/67, Bd. 35, fol. 6803; Wilhelm Kube to Hinrich Lohse, February 6, 1942, StA Hamburg 147 Js 29/67, Sonderband E, fols. 66 f.; Minutes of the Proceedings of the Office and Section Leaders Meeting, January 29, 1942, Zentrales. Staatsarchiv Minsk 3701-53, fols. $164 \mathrm{f}$. (a document first uncovered by Jurgen Matthaus). In a report by the adviser on Jewish affairs for the Commander of the Security Police, Kurt Burkhart, dated January 1942, it is also hinted that the German Jews are to die (IfZ Fb 104/2). For the period prior to January 20, 1942 there is no sure evidence for any executions of German Jews in Minsk.

${ }^{206}$ See Karl Loewenstein, Minsk. Im Lager der deutschen Juden (Bonn, 1956); Heinz Rosenberg, Jahre des Schreckens (Gottingen, 1992); for the date of March 31, see Anna Krasnoperka, Briefe meiner Erinnerung (Haus Villigst, 1991), pp. 56 f. 
tions of 150,000 Jews from the German Reich to concentration camps announced by Himmler on the same day had to be delayed for a time owing to the rail crisis. ${ }^{207}$ In late March the deportation of French and Slovakian Jews to the Lublin district and to Auschwitz began. At first, they were still viewed as laborers, but many of them died quickly. German Jews were brought to the Lublin district. Initially they were housed in the ghettos once inhabited by the Polish Jews who had been executed. In April 1942 the Reich Railway could again supply thirty-seven special trains for Jewish deportations. ${ }^{208}$

At the beginning of May 1942 a coordinated action began involving the transport of German Jews directly to various extermination sites. Between May 4 and 15, 1942, the first 10,161 German Jews were transported from the Lodz ghetto and exterminated in gas chambers in Chelmno. ${ }^{209}$ On May 6, the first fatal transports left the Reich from Vienna, bound for Minsk. On May 11, 1942, these deportees were shot or gassed in the camp at Trostinez. ${ }^{210}$ On May 2, Undersecretary of State Martin Luther from the foreign office issued assurances to the Slovakian government that Jews deported from Slovakia would never return. ${ }^{211}$

On April 17 Himmler visited Kolo (Warthbrucken), the transfer point for Jews being deported from Lodz. It is possible that he visited the nearby extermination camp Chelmno as well. On June 18, 1942, Reich Interior Minister Frick also visited Kolo. According to a witness, local residents complained to Frick about episodes of brutality during the "reloading." Frick saw to it that subsequent trainloads of Jews were transported to their final destination on

${ }^{207}$ Adler, p. 193; Teletype from Himmler to Richard Glucks, Inspector of.the Concentration Camps, January 25, 1942, NS 19/1920, fol. 1; Klaus A. Friedrich Schuler, Logistik im Russlandfeldzug (Frankfurt am Main, 1987), pp. $518 \mathrm{ff}$.

${ }^{208}$ Office of the Deputy for the Four-Year Plan, Traffic Office, Activity Report for April, May 18, 1942, BA R 26 IV/vorl. 47; Arad, Belzec, Sobibor, Treblinka, pp. 140, 147; Pohl, Lublin, pp. $107 \mathrm{ff}$.

${ }^{209}$ Proclamation of the Jewish Council, May 1, 1942; Situation Report of the Office of State Police in Litzmannstadt, June 9, 1942; Director of the Office for Railroads and Traffic to Gestapo Office Litzmannstadt, May 19, 1942, all in Adolf Diamant, Getto Litzmannstadt (Frankfurt am Main, 1986), pp. 107, 120, 125; Lucjan Dobroszycki, ed., The Chronicle of the Lodz Ghetto, 1941-1944 (New York and New Haven, Conn., 1984), pp. 156-72 (for April 29-May 14, 1942); Freund, Perz, and Stuhlpfarrer, eds., esp. p. 29.

${ }^{210}$ Transport Lists of the Vienna Transports, Staatsanwaltschaft Koblenz 9 Ks 2/62, Dok. vol. 5; interrogation of Survivor J.S., April 11, 1948, StA Koblenz 9 Ks 2/62, vol. 71, fol. 10546; Minsk Railway Control Office, Rail Service Telegram, May 7, 1942, ZStA Minsk 378-1-784, fol. 64; Activity Report of the Second Wing of the Waffen-SS Battalion for Special Projects, May 17, 1942, in Unsere Ehre heisst Treue (Vienna, 1984), p. 246.

${ }^{211}$ Christopher Browning, "A Final Hitler Decision for the 'Final Solution'? The Riegner Telegram Reconsidered,' Holocaust and Genocide Studies 11, no. 1 (1996): 3-10, esp. p. 4; Aly, p. 408. 
the narrow gauge railway. ${ }^{212}$ Frick's visit occurred shortly after the systematic extermination of the German Jews in Chelmno had begun. Up until the end, the Reich interior ministry sought to assert its authority.

The National Socialist Party played a significant role in this newly accelerated genocide of European Jews and of German Jews. In the face of the countless, often desperate requests submitted by Jewish citizens and their nonJewish advocates, Bormann issued two directives to the Gauleiter and Kreisleiter at the end of June and the beginning of July 1942. He instructed them to subject any requests for exceptions to the "most meticulous scrutiny." Lammers followed suit in a directive to government offices. ${ }^{213}$ Bormann went one step further on October 9, 1942. In a confidential memorandum he offered a justification for the extermination of the Jews and issued gag orders to party functionaries. He seems to have wanted to counter rumors circulating about "extremely harsh measures" being taken against the Jews while at the same time apparently justifying them. Bormann's text was a short and simple paraphrase of the presentation Heydrich gave according to the minutes of the Wannsee Conference. ${ }^{214}$

The question may well be raised, in conclusion, as to the value of the evidence presented in this essay. Does the thesis that Hitler made a decision in principle in early December 1941 to exterminate all European Jews contradict any supposedly secure results of previous research? If not, what significance does it possess?

A comprehensive directive by Hitler authorizing the extermination of European Jews has never been discovered. Nor is there any evidence to suggest that such a directive ever existed. But the same could be said about any supposed personal decision by Hitler. Theoretically such a decision might have occurred long before any directive was ever issued. Clearly, an inner decision is much

${ }^{212}$ It is not certain whether this incident actually occurred. For Himmler, see Witte, p. 335. For Frick's visit to the Landrat's Office in Kolo (Warthbrucken), see Ruckerl, p. 277 (for the eyewitness account); aide to the Reich minister of the interior, travel plan, June 15-27, 1942; newspaper article [probably from the Ostdeutschen Beobachter] "Besuch im Osten des Warthelands," BA R 18/5231, fols. 99 ff., 115. According to the schedule and to the report, a visit by Wilhelm Frick to Chelmno itself, as asserted in the witness account, is unlikely. With regard to complaints lodged following the murders in Chelmno in February, see Seeger, p. 121.

${ }^{213}$ NSDAP, Party Chancellery, "Reichverfugungsblatt,” Ausgabe A, July 1 and July 4, 1942, with Regulations 34/42 and 37/42, in re: Treatment of Part-Jews in the Armed Forces, June 23, and in re: Recommendations for Part-Jews from the Party, July 3, 1942, BA 62 Ka 1, Nr. 83, fols. 128 f.; see also Adler, p. 298.

${ }^{214}$ Circular letter from the Party Chancellery, in re: Preliminary Measures for the Final Solution of the Jewish Question in Europe. Rumors concerning the Situation of Jews in the East, October 9, 1942, in Patzold, ed., pp. 351-53. 
more difficult to substantiate than a directive. ${ }^{215}$ All the various theories about when Hitler decided to exterminate the Jews employ the same method: they try to juxtapose some supposed development of plans or preparations for executions with statements made by Hitler that seem to indicate that he had made such a decision. But the latter are generally unclear or ambiguous.

The decision to execute Soviet Jews must be distinguished from the decision to destroy the remaining European Jews. Most historians now make this distinction. ${ }^{216}$ The former decision was made much earlier than the latter, by August 1941 at the latest. In my view it had already been made in the first months of that year. ${ }^{217}$

The notion that the decision to deport the German Jews was equivalent to the decision to exterminate them has no evidence to support it. It is contradicted by events at Lodz, Minsk, and Riga. One of the purposes of the Wannsee Conference was to discuss the unresolved issue of what to do with the German Jews. It is also entirely possible that Hitler first announced his decision after the conference had been initially scheduled. ${ }^{218}$ The issue was ripe, so to speak. Himmler, Heydrich, Rosenberg, and Lohse all apparently urged that at least some of the deported Jews be executed. Nonetheless, a decision by Hitler on the subject has not previously been documented. Nor do we have evidence of any decision by him with regard to plans for the deportation of Jews from France in the fall of 1941. In the French case, however, it was a matter first of all of deporting, and possibly executing, just a limited number of Jews who were already in custody, or who were being held as hostages. The permission to do so did not yet apply to all French Jews. ${ }^{219}$

There is no disputing the fact that on several occasions Hitler merely ap-

${ }^{215}$ It is certain, however, that Hitler was well informed about the progress of efforts to exterminate the Jews and never rejected the idea. See Fleming; Burrin; Broszat.

${ }^{216}$ See nn. 16 and 17. This is made especially clear in Burrin, pp. 106 ff.; Browning, "Euphoria," p. 476.

${ }^{217}$ And it was made after Hitler had approved related plans by military and civilian offices for an unparalleled program of mass murder to be carried out against large segments of the Soviet population for economic and military purposes. For more on this subject, see Gerlach, "Wirtschaftsinteressen" (n. 10 above).

${ }^{218}$ Hitler's leadership decision would then have had significant consequences for the Wannsee Conference by putting it, and Heydrich's planning for it, on a new basis and giving it added impulse. This may have contributed to the lengthy delay in rescheduling the conference.

${ }^{219}$ For a different interpretation, see Burrin, p. 145. But even Heydrich's letter of November 6, 1941, cited in Burrin, in which he reports that "at the highest level, and with utmost severity, the Jews have been branded as the real incendiary force in Europe," does not provide proof. In addition, see Witte, pp. 327-29; German ambassador in Paris, Carltheo Zeitschel, to the chief of the Security Police for Belgium and France, October 8, 1941, in Patzold, ed., pp. 309 f.; teletype from Himmler to Heydrich, January 27, 1942, BA NS 19/1920, fol. 2 in regard to the limited number of individuals. 
proved the antisemitic measures and partial extermination programs that had been developed by others and that he did not often devise or promote plans of his own. At the Wannsee Conference, Heydrich himself remarked that the deportation of Gerrman Jews had begun in September 1941 after "prior approval from the Fuhrer." ${ }^{220}$ He surely would not have dared, nor would he have wanted, to use the term "approval" if in fact it had been at Hitler's order. In similar fashion Hitler approved the execution of Jews in the newly occupied area of France on December 10, 1942, and the extermination of the remaining Polish and Soviet Jews on June 19, 1943.221

If one can believe the testimony of Eichmann, who claimed to have acted as the messenger, on two or three occasions during the early stages of extermination efforts in the General Government, Odilo Globocnik received permission from Heydrich to execute a limited number of Jews-in each case groups of 150,000 to 250,000 individuals. ${ }^{222}$ Here, too, it was a regional initiative that was approved, though admittedly one that was closely tied to the whole European-wide extermination program. The extermination camp at Belzec, whose construction had begun as early as November 1941, was initially designed to experiment with methods for mass extermination of Jews by poison gas in stationary gas chambers and then to carry out the first efforts. ${ }^{223}$ The scheme may have been preceded by permission from Hitler or by a decision from him, but up until now none has been documented. Exactly what future expectations were associated with the erection of the Belzec camp remains unknown.

Evidence recently uncovered indicates the probable existence of a plan to deport some Jews from the rest of Europe to Mogilev, in White Russia. The same evidence indicates the construction of a crematorium at the close of 1941 and a possible plan for construction of a gas chamber. ${ }^{224}$ But none of this provides unconditional proof that there existed a comprehensive plan for the extermination of the Jews. Exactly when a gas chamber was planned there remains uncertain. The intention could well have been to transport a large number of Jews there, to employ them at forced labor, and to let them perish from inhuman living conditions. ${ }^{225}$ Rosenberg's remark on November 18, 1941, three

${ }^{220}$ Minutes, fol. 5 (Tuchel, p. 126).

${ }^{221}$ See Broszat, pp. $766 \mathrm{ff}$.

${ }^{222}$ On one occasion, however, this is said to have occurred after the fact; see Pohl, Lublin, p. 125.

${ }^{223}$ See ibid., esp. pp. 101, 115; Aly, p. 398.

${ }^{224}$ Aly, pp. 339-47; Christian Gerlach, "Failure of Plans for an SS Extermination Camp in Mogilev, Belorussia," Holocaust and Genocide Studies 12, no. 1 (1997): 60-78.

${ }^{225}$ A recently discovered document regarding a significant increase in the area included in the town's ghetto could provide some indirect evidence of this. Nearly all of the ghetto's original residents were shot in October. See Jurgen Matthaus, "Perspektiven 
days after a meeting with Himmler, that the occupied Soviet territories were to serve as the location for a "biological extermination of the whole of European Jewry," could also have been intended to refer to a slow process of annihilation, but he considered this to be possible only in the distant future. Rosenberg and Himmler had met with Hitler on November 16, following their own conversation the previous day. Then, on November 17, Himmler had a telephone conversation with Heydrich on the subject of the "removal of the Jews," but this may have been with reference to the topic they discussed previously, "the situation in the General Government," or to difficulties concerning the deportation of Jews from the German Reich to the East. Heydrich discussed the last subject with Goebbels on the same day. ${ }^{226}$ As of October 13 Rosenberg had continued to declare that a deportation of Jews living in the General Government to the occupied territories of the Soviet Union was impossible. All he could give were vague promises for the future. These were of dubious value. In any case Rosenberg withdrew them in the middle of December. ${ }^{227}$ An article written by Goebbels for the weekly Das Reich on November 16, 1941, which has sometimes been interpreted as proof of the existence of a comprehensive plan for extermination, is in fact ambiguous. In that article Goebbels defended the deportation of Jews from Germany because there had been some indications of solidarity with them by segments of the non-Jewish population. Goebbels wrote that "Jewry" was "facing a gradual process of destruction." ${ }^{228}$ All this evidence indicates that the events that occurred in the fall of 1941 will have to be examined further before a final judgment can be made. ${ }^{229}$

In the final analysis, what really matters is that the suggestion that there

der NS-Forschung," Zeitschrift fur Geschichtswissenschaft 44 (1996): 991-1005, esp. p. 1002.

${ }^{226}$ For Rosenberg's speech, see n. 73. Cf. Jochmann (n. 30 above), p. 140; and Himmler's notes on telephone conversations, November 17, 1941 (n. 27 above). For an interpretation of the latter as a comprehensive agreement with Hitler concerning the liquidation of the Jews, see. Breitman, pp. $218 \mathrm{f}$. (also for the other mentioned contacts). See also Goebbels, Tagebucher, pt. 2, vol. 2, p. 309. I am indebted to Christoph Dieckmann, who referred me to that document.

${ }^{227}$ Prag and Jacobmeyer, eds., October 14 and December 16, 1941, pp. 413, 457.

228 "Das Reich" No. 46 of November 16, 1941, p. 1 f. A similar report on some of Hitler's remarks by Goebbels on August 18, 1941.(Broszat, pp. 749 f.) referred only to events "in the east." See in addition an article in the Volkischen Beobachter, Munich ed. (November 12, 1941), referring to Hitler's speech on November 9 (BA NS 22/567, fol. 1).

${ }^{229}$ The same is true of the background to Hitler's remarks on November 28, 1941 to the Grand Mufti of Jerusalem, Haj Amin El Husseini, when Hitler asserted that, in the event of a German advance into the Middle East, the German objective would be the "destruction" of "Judaism" in Palestine. Hitler could have had tactical reasons because El Husseini had asked him for such a statement during the meeting. Note of Gesandter Schutt about the discussion between Hitler and El Husseini of November 28, 1941, in Akten zur deutschen auswartigen Politik, Ser. D, vol. 13, 2 (Gottingen, 1970), pp. 718-21. 
never was a central decision made by Hitler regarding the extermination of the European Jews cannot be sustained. ${ }^{230}$ Equally unsupportable is the thesis that the final decision was not made until May or June of $1942 .{ }^{231}$ The fundamental decision announced in December of 1941 is a crucial missing piece of the decision-making process leading up to the liquidation of the Jews. Hitler's decision put the planning for these crimes on a new basis. But it relieved no one of responsibility. Its result was that the various existing ideas, proposals, and initiatives for extermination projects at the regional levels received support and legitimation. They received new impetus and became systematized. Significantly, only four days before the Fuhrer's decision, and independent of it, the first extermination camp at Chelmno had begun its grisly work. ${ }^{232}$ Arthur Greiser had literally received special permission from Himmler and Heydrich to execute one hundred thousand Jews. It is unlikely that Hitler was involved. If Greiser had received permission from Hitler he would not have had to express his gratitude to Himmler, yet he did so. ${ }^{233}$

Let me make the following points clear. The purpose of my essay has not been to reject the results of more than twenty years of basic research, particularly by the so-called functionalist school. The extermination of the Jews was by no means based either simply on this one decision by Hitler or even on the entirety of his decisions, directives, or initiatives. What we are concerned with is one significant point within a whole process that led to the liquidation of the

${ }^{230}$ See Hans Mommsen, "Die Realisierung des Utopischen: Die 'Endlosung der Judenfrage' im 'Dritten Reich,'” in Der Nationalsozialismus und die deutsche Gesellschaft, ed. Mommsen (Reinbek, 1991, 1st ed., 1983), pp. 184-232, esp. p. 214.

${ }^{231}$ Compare Jean-Claude Pressac, Die Krematorien von Auschwitz (Munich and Zurich, 1993), esp. pp. 51-55; in regard to Broszat, see Aly (n. 5), p. 398, for comments typical of the opinions of some scholars who nowadays favor this view.

${ }^{232}$ Conversely, Hartog, pp. 65-69, sees a direct connection between the entry of the United States into the war and a decision he believes Hitler made immediately on December 7, 1941. Based on some mistaken dates he concludes that Hitler needed only to "nod his head," since "Himmler and Heydrich had already known for months that Hitler intended to liquidate the Jews throughout Europe" (p. 65). Nonetheless, at a meeting in the Reich labor ministry on November 28, 1941, the representative from the Wartheland noted that "some 300,000 Jews were still living" in his district. He continued that "by the end of March 1942, they should all have been evacuated, with the exception of those able to work." That could only have meant their extermination at Chelmno. If one follows Hartog, the administrative offices in the Wartheland could only have developed this schedule if they had known in advance about the impending Japanese attack on Pearl Harbor, which they surely did not. See report on the department meeting in RAM (undated [November 28, 1941]), BA R 22/2057, fol. 208. For the date, see fols. $206 \mathrm{f}$.

${ }^{233}$ Greiser to Himmler, May 1, 1942, BA NS 19/1585, fols. $1 \mathrm{f}$. For the fall of 1942 it has been documented that Arthur Greiser asked Hitler what measures should be taken in his district against the Jews and that Hitler told him to proceed "as he thought appropriate." Greiser to Himmler, November 21, 1942, BA NS 19/1585, fols. 17 f. Aly mistakenly refers to this as the fall of 1941 . 
European Jews. Among other things, the analysis of this impulse can contribute to a more precise view of Hitler's actual role. It certainly is difficult to understand how Hitler could have made a fundamental decision in principle to exterminate all the Jews in Europe only after nearly one million Jews had already fallen victim to organized mass murder in a number of countries. It is difficult to comprehend that this decision was not made all at once but rather step by step in one area after another. But this is precisely what the case of Chelmno indicates. The prevailing view that the fundamental decision had already been made between the spring and the fall of 1941 is based on the belief that some kind of prior approval by the government leadership must have preceded the transition to mass murder of the Jews. For the National Socialists, however, the various decisions to proceed with the exterminations were political and not moral decisions. They could thus be made and applied in limited fashion to specific territories or to particular groups of individuals - those "incapable of work," for example.

How are the contents and results of Hitler's fundamental decision to be evaluated? His remarks on December 12 were contained in a relatively brief passage within a long speech. At the time, the attention of the German leadership was far more intently focused on political problems that were seen as much more urgent than the persecution of the Jews. This small part of the address was clear and unambiguous, but it still was not specific. We have to remind ourselves that Hitler's various meetings with Himmler, Bouhler, Frank, Rosenberg, and others would have been much more detailed and concrete. As far as the events of December 1941 are concerned, it is not a matter of whether or not the historical agents used a more or less radical language (since they did that at other times as well). Rather it is a matter of ascertainable consequences. To summarize, Hitler's December 12 speech and the other meetings had three crucial results: (1) new, fundamental directives regarding the execution of all Jews by the General Government and by the Ministry for the East, the administrative units with control over the majority of Jews living in areas under German rule; (2) an intensification of planning and of preparations for exterminating the Jews in various regions using poison gas; and (3) a determination of policy regarding German Jews. In announcing his decision to exterminate all European Jews, Hitler had also decided the fate of the deported German Jews. The last point is confirmed, for example, by Hans Frank's remark in Krakow on December 16, 1941, concerning the executions of the Jews in the General Government: "Whatever happens in the Reich will at the very least have to happen here as well." 234

For the officials involved, Hitler's decision was a necessary one as far as it

${ }^{234}$ Hans Frank's speech at the government session in Krakow on December 16, 1941, BA R 52 II/241, fol. 77. 
concerned the execution of German Jews. It was also necessary as a basis for the centralized planning of the mass exterminations. Despite their use of language aimed at cloaking the realities, the indications in Frank's speech in Krakow on December 16 and in Heydrich's address as recorded in the minutes of the Wannsee Conference must be taken seriously. We witness there the initial sketches of a comprehensive plan for total liquidation. Prior to this there had not existed such a comprehensive plan for systematic extermination to be carried out within a brief span of time. With regard to the savage treatment already being meted out to Jews in the occupied territories of the Soviet Union, the new directives of December 1941 hardly meant much. They may have had a slightly greater effect in the General Government, though there, too, regional impulses from the police and from elements in the civil administration in favor of large-scale exterminations had already become so powerful that sooner or later a catastrophe was inevitable.

What this evidence shows is that Hitler by no means decided everything, even in what may have been his most significant intervention in the processes leading to the mass exterminations. Nor did he need to decide everything. The results of his intervention were clear, but in a certain sense they were also limited. Earlier findings by various researchers as to the grave responsibility shared by other official bodies, particularly by the authorities directly in charge in the occupied territories, are confirmed by our analysis.

In order to understand the decision-making process that led to the destruction of the European Jews it may be useful to refer to the concept of the utopian. The National Socialists, with Hitler foremost among them, certainly entertained ideas about eliminating the Jews and indicated a willingness to put these ideas into practice well before 1941. But there is a difference between having ideas or intentions to exterminate a people and the actual implementation of those ideas and intentions. The initial schemes for a "Final Solution" involved various plans for a forced migration. They were markedly destructive in character, with features such as slow annihilation through brutal living conditions and limits on reproduction. In a way, however, these plans were also utopian, principally because none of them, however seriously pursued, had any practical chance of being realized. This was as true of the Madagascar plan as it was of the 1939-40 plan to deport Jews to the Lublin district. Destructive elements grew more pronounced in the plan to deport European Jews to conquered regions of the Soviet Union following a successful conclusion of the war there. Exactly how to go about exterminating the Jews became imaginable only little by little, even though a widespread readiness to do so had long existed. What was decisive for the actual realization of mass murder plans were the intermediate steps between the utopian emigration and extermination schemes, on the one hand, and liquidation programs that could be practically implemented, on the other. The scheme proposed at the outset of 1941 to re- 


\section{Gerlach}

duce some thirty million individuals in the Soviet Union to starvation in order to guarantee food supplies to the European areas controlled by Germany proved to be impractical. It was replaced in the fall of 1941 by programs for eliminating groups of specific individuals, like the millions of Soviet war prisoners who were "incapable of work." For the antisemitic efforts, the steps undertaken in December 1941 marked an ominous turn toward the practical implementation of concrete measures for racial genocide.

Although these monstrous developments could certainly not be called normal politics, and although Hitler intervened directly, in one sense this life or death decision regarding the fate of the Jews living in Europe came tọ pass in a manner very much like any other "normal" political decision. The Fuhrer did not make the decision alone; he made it only after some time had passed; and, in a specific situation and for a specific set of reasons, he gave his approval to initiatives that had arisen from the administrative and party apparatus. As with many evolving policies, the demands for the extermination of the European Jews came from many sources. Before they could all be acted upon in some systematic manner, however, the National Socialist system required a leadership decision by Hitler. 